
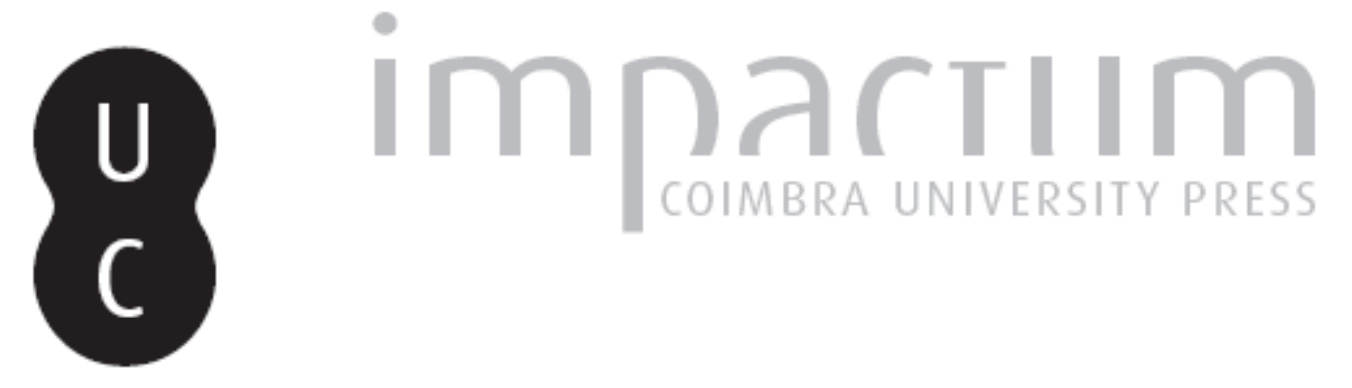

\title{
$01 .^{\circ}$ centenário pombalino (1882): contributo para a sua compreensão histórica
}

\author{
Autor(es): Bebiano, Rui
}

Publicado por: Imprensa da Universidade de Coimbra

URL persistente:

URl:http://hdl.handle.net/10316.2/43919

DOI: $\quad$ DOI:https://doi.org/10.14195/2183-8925_4-2_16

Accessed : $\quad$ 26-Apr-2023 13:02:16

A navegação consulta e descarregamento dos títulos inseridos nas Bibliotecas Digitais UC Digitalis, UC Pombalina e UC Impactum, pressupõem a aceitação plena e sem reservas dos Termos e Condições de Uso destas Bibliotecas Digitais, disponíveis em https://digitalis.uc.pt/pt-pt/termos.

Conforme exposto nos referidos Termos e Condições de Uso, o descarregamento de títulos de acesso restrito requer uma licença válida de autorização devendo o utilizador aceder ao(s) documento(s) a partir de um endereço de IP da instituição detentora da supramencionada licença.

Ao utilizador é apenas permitido o descarregamento para uso pessoal, pelo que o emprego do(s) título(s) descarregado(s) para outro fim, designadamente comercial, carece de autorização do respetivo autor ou editor da obra.

Na medida em que todas as obras da UC Digitalis se encontram protegidas pelo Código do Direito de Autor e Direitos Conexos e demais legislação aplicável, toda a cópia, parcial ou total, deste documento, nos casos em que é legalmente admitida, deverá conter ou fazer-se acompanhar por este aviso.

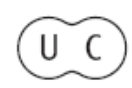




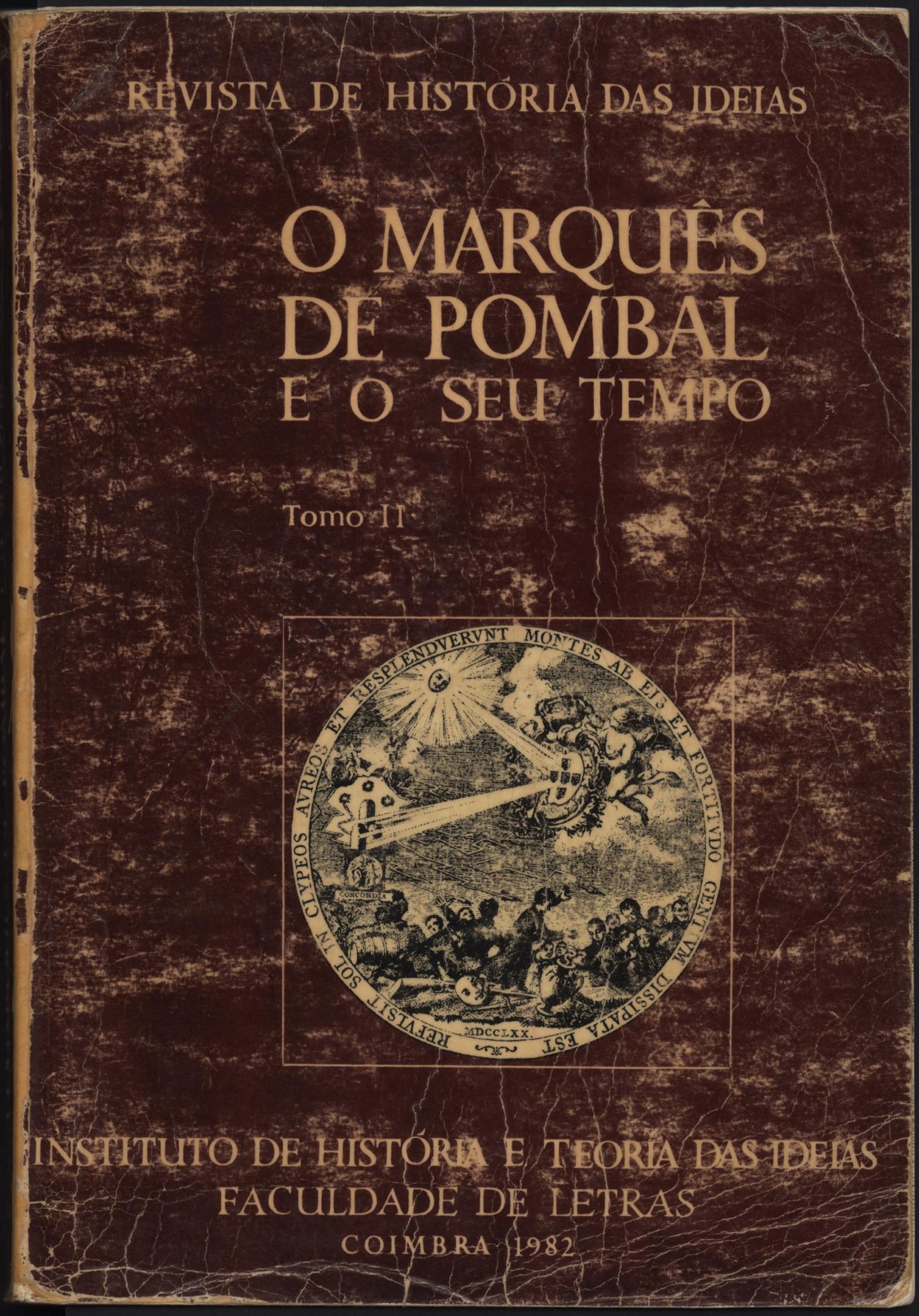




\title{
O $1 .^{\circ}$ CENTENÁRIO POMBALINO (1882)
}

\author{
Contributo para a sua compreensão histórica
}

A celebração do segundo centenário da morte do Marquês de Pombal tem lugar de uma forma mais ou menos silenciosa. No resguardo dos seus gabinetes de trabalho, homens da cultura examinam e pensam a obra de um português que, indelevelmente, marcou o seu tempo e os destinos da nossa terra. Depois, o produto do seu esforço será transmitido ao número, sempre limitado, daqueles que partilham das suas dúvidas e ânsias de conhecer. Num determinado sentido, é tal situação absolutamente compreensível: a figura e a obra de Sebastião José de Carvalho e Melo, volvidos que são duzentos anos sobre a sua morte, adquiriram, pelo mérito próprio que o tempo cimentou, o lugar seguro de um marco histórico que importa atender. Mais do que isso-e ressalvando um anti-pombalismo latente ou manifesto que a viradeira mariana, o legitimismo miguelino, o integralismo e um certo salazarismo precisaram de cultivar - a acção histórica de Pombal tendeu, também, a incorporar-se no Olimpo do nosso universo sebástico, como mítico arquétipo de novo Salvador, que de há muito os portugueses se habituaram a imaginar e a projectar em sucessivas gerações de «desejados». No geral, porém, a figura do Marquês asseptizou-se, numa postura que requer de nós um esforço de compreensão e de interpretação, mas que se situa à margem dos grandes títulos jornalísticos e das conversas de rua.

Há cem anos atrás, a situação era profundamente diversa. Num Portugal coberto ainda pelas feridas abertas pelo processo político que se activara em 1820 , feridas que a «Regeneração» não pudera (ou não soubera) cicatrizar, a figura

(*) Faculdade de Letras da Universidade de Coimbra. 
de Pombal surgia inscrita nas bandeiras de luta daqueles que propunham manter viva a chama liberal, opondo-se à ainda presente reacção legitimista ou, de uma forma mais radical e elaborada, propondo uma alternativa política e institucional à monarquia que entendiam moribunda. Não porque a figura do Marquês pudesse ser apontada como a de um liberal - não o fora de todo - mas porque, pela sua acção enérgica e até certo ponto inovadora, constituía um acidente no percurso da política portuguesa. Assim se compreenderá, então, o impacto, sentido mesmo ao nível do quotidiano do comum dos portugueses, que tiveram as comemoraçōes do primeiro centenário da morte do Marquês de Pombal, envolvendo em polémicas acesas e apaixonadas as mais diversas correntes de opinião política e social.

E justamente o significado desse facto que começámos a entever, ao longo do estudo que nos conduziu a estas linhas. Lançando um olhar que focasse os acontecimentos de Maio de 1882, foi todo um complexo de circunstâncias que acabámos por ter de apreciar, de forma a poder entender, satisfatoriamente, o sentido autêntico das comemorações. Para tal tivémos, como ponto de partida, que procurar ajuizar a situação política que se vivia em Portugal na alvorada do último quartel do século XIX.

\section{A POLÍTICA PORTUGUESA EM 1882}

\section{O Poder}

O movimento insurreccional que, conduzido por Saldanha, eclode e se torna vitorioso em Abril de 1851, representa, em termos ideais, um ponto de viragem no curso da vida portuguesa oitocentista. Não por se tratar de acção revolucionária capaz de alterar de uma forma profunda e imediata as instituições e a sociedade, mas, essencialmente, porque colocou um solene ponto final na agitação política e no constante clima de guerra que devastava o país desde os inícios do século, permitindo, num mesmo tempo, que se começassem a estabelecer as condições que possibilitassem a exequibilidade de um projecto económico e político que ia ganhando corpo. A Revolução Liberal, de feição predominantemente comercial, rural e civilista, encontrava-se vitoriosa, mas o capitalismo procurava ainda, ansiosamente, as vias para um desenvolvimento pleno.

De facto, a ainda incipiente burguesia portuguesa de inícios de século crescera, acompanhando o desenvolvimento dos 
diversos sectores produtivos que a legislação pós-1820 viera libertar das peias constrangedoras do «antigo regime». Esta situação, nova e necessariamente inovadora, não era compatível com a inquietação constante que a luta política violenta impunha, traduzindo-se tal limitação na inibição a um desenvolvimento constante e seguro, capaz de satisfazer os intuitos de acção, contínua e progressiva, dos empresários potenciais. Ao mesmo tempo, a derrota do movimento revolucionário europeu de 48 e o triunfo do industrialismo prenunciavam novos ritmos - económicos, técnicos, sociais, políticos, mentais - para a vida da segunda metade do século. Em tais condições, tornava-se necessário (ou melhor, absolutamente vital) para as classes possidentes, um governo forte, ainda que maleável, o qual, sem promover o regresso ao antigo estado de coisas, garantisse a expansão económica e promovesse a tranquilidade política, com base num programa minimamente preciso de desenvolvimento das forças produtivas e de reformas sociais $\left({ }^{1}\right)$, capazes estas de enquadrarem um operariado que crescia e ensaiava as primeiras formas de organização reivindicativa. Tal como, de uma forma particularmente límpida, Oliveira Martins escreveria no Portugal Contemporâneo, «entre o romantismo liberal e a democracia futura está a regeneração (nome português do capitalismo), um período triste, mas indispensável como consequência do antecedente e preparação do ulterior» $\left({ }^{2}\right)$.

A «Regeneração» e o fontismo irão então assumir-se como pragmática tentativa de superação das limitações e dos sucessivos malogros do vintismo, do cartismo, do setembrismo e do cabralismo, apontando para uma acção concreta e rápida no sentido da modernização do país, o que, em verdade, se vai lentamente começar a conseguir, através de medidas que logo o primeiro governo da «Regeneração» irá tomar. O ano de 1852 é, pode dizer-se, o ano de arranque do capitalismo modeno em Portugal: decreta-se o novo Código Penal c cria-se o Ministério das Obras Públicas, que tantos investimentos de capital irá proporcionar, inicia-se o processo de construção dos caminhos de ferro e converte-se em títulos a dívida pública, ao mesmo tempo que se reforma o serviço de correios, se começa a trabalhar no melhoramento da rede viária e se lança o telégrafo.

(') Veja-se Manuel Villaverde Cabral, $O$ desenvolvimento do capitalismo em Portugal no século XIX, Lisboa, A Regra do Jogo, 1977, p. 164.

$\left(^{2}\right)$ Oliveira Martins. Portugal Contemporâneo, 8.a ed., vol. II, Lisboa, Guimarães \& C.a, Editores, 1979, p. 240. 
Mas este afã inovador vai ser limitado e impedido de avançar por algo que de certa forma o ultrapassa. Trata-se daquilo que poderemos designar por "movimento de compressão" das estruturas da antiga sociedade sobre aquelas medidas políticas, mais ou menos impostas por iniciativa governamental. Uma sociedade economicamente fundada numa agricultura tradicional, dotada de uma burguesia jovem e ainda reduzida, virada essencialmente para as operações especulativas, não podia, de forma alguma, ser terreno de cultura do capitalismo industrial $\left({ }^{3}\right)$. A proposta "regeneradora» pouco mais será então do que «um capitalismo tardio, de curtos voos, que se diria compelido - e limitado - à transferência do atavismo estrutural da renda agrícola para a agiotagem dos juros» $\left({ }^{4}\right)$, servindo o aparelho de Estado, em constante expansão, como base sólida para as operações financeiras. Simultaneamente, a constituição de grupos económicos poderosos, nesta base levantados, capazes de controlar muitos dos servicos de interesse público, bem como o crescimento do funcionalismo, motivado pelas novas necessidades administrativas (e exército de reserva para a formação de clientelas eleitorais), íam conduzindo o regime a uma situação de imobilidade política.

O rotativismo irá, pois, constituir-se como a alternância no poder de dois blocos, assegurando dessa forma, sem sobressaltos, a ordem política monárquica e a manutencão de um estado de coisas que equilibrasse e regulasse a acção dos grupos económicos e da sua componente política. Mostra-se, assim, incapaz de suscitar as profundas alterações estruturais de que a sociedade portuguesa carecia e, também, cioso de um regime parlamentar e laico, do qual se nutria e que olhava os derradeiros mas irrequietos legatários do miguelismo como vestígios de um passado definitivamente ultrapassado.

Será este o sistema que governará a monarquia quase até ao seu derrube, se ressalvarmos curtos períodos necessários para a recomposição das forças políticas e sociais ou atravessados por curtas experiências autoritárias, oferecendo ao país o espectáculo afrontoso de uma política elaborada à luz dos interesses dos grupos, eivada de constantes escândalos e tendente a empurrar progressivamente um vasto sector da população para a oposição ao regime.

(') Veja-se Vitorino Magalhães Godinho, Estrutura da antiga sociedade portuguesa, 3. ${ }^{\mathrm{a}}$ ed., Lisboa, Arcádia, 1977, pp. 141-163.

(4) Joel Serrão, artigo «Regeneração», in Dicionario da História de Portugal, 5. vol., Lisboa, Iniciativas Editoriais, 1975, p. 251. 
No período que especialmente nos interessa analisar, isto é, nos inícios do último quartel do século XIX, o rotativismo tomava corpo na alternância no poder do Partido Regenerador, chefiado por Fontes Pereira de Melo, e do Partido Progressista, resultante da fusão, em 7 de Setembro de 1876, dos partidos Histórico e Reformista, e liderado por Anselmo Braamcamp. Da real consistência política destes partidos nos dão conta as suas práticas e métodos governativos, semelhantes no essencial da sua função de gestores da monarquia, e até os seus textos programáticos, totalmente inexistentes para o Partido Regenerador e bastante genéricos no caso do Partido Progressista $\left({ }^{b}\right)$.

Batendo-se por vezes violentamente (de um ponto de vista verbal, entenda-se), as duas forças vão poder manter-se alternadamente no poder, revezando-se de uma forma mais ou menos regular, mas não sem que, aqui e além, fossem recebendo os primeiros embates de uma oposição anti-monárquica em vias de organização.

\section{Os republicanos}

Será sobretudo no período que medeia entre o ministério Fontes de 1881 e a agitação que envolverá, em 1890, a questão do ultimatum, que a sociedade portuguesa toma, definitivamente, essa feição especial, caracterizada pela predominância daquelas "oligarquias político-financeiras» $\left({ }^{6}\right)$, progressivamente afastadas do país real, criando-se assim as condições para o desenvolvimento de um projecto alternativo, capaz de mergulhar as suas raízes na massa crescente de descontentes. Foi esta a aposta de republicanos e socialistas, que os primeiros seriam capazes de conduzir à vitória.

O sonho republicano, porém, vinha detrás. Sectores radicais do vintismo tinham-no já entrevisto $\left({ }^{7}\right)$. Mas, de uma forma explícita e minimamente consistente, e como acentuou Joaquim de Carvalho, «o republicanismo português nasceu

${ }^{(5)}$ Veja-se J. F. Trindade Coelho, Manual politico do cidadão portuguez, Lisboa, Parceria A. M. Pereira, 1906, pp. 596-658.

$\left.{ }^{\circ}\right)$ Francisco Reis Santos, «O movimento republicano e a consciência nacional», in Historia do Regimen Republicano em Portugal, dir. de Luis de Montalvor, tomo I, Lisboa. Ed. Século, 1930, p. 307 .

(') Veja-se Luis Reis Torgal, «A imprensa estudantil de Coimbra e o radicalismo liberal vintista», in $O$ Liberalismo na Península Ibérica na primeira metade do século XIX, vol. 2., Lisboa, Sá da Costa, 1982, pp. 241-256. 
das denegações e das estreitezas da política cartista, em condições que no-lo apresentam como herdeiro do liberalismo" $\left({ }^{8}\right)$. Com efeito, a ditadura de Costa Cabral e a sua política desastrosa, a sublevação contra essa política e o esmagamento da Patuleia, haviam começado a trazer à luz do dia as contradições do liberalismo monárquico, até então somente contestado de uma forma individual, como acontecera com Castilho no seu prefácio às Palavras de um crente, obra que traduz em $1836\left({ }^{9}\right)$. E, pois, em meados do século, e também como fruto dos acontecimentos que em 1848 abalaram a Europa, que surgem as primeiras manifestações de um sólido espírito republicano, apontando a eliminação da coroa como a única via pela qual poderia passar toda a transformação do país, num sentido autenticamente liberal e superador dos arcaísmos estruturais. Todavia, estas manifestações não constituem ainda muito mais do que actos isolados, circunscritos a limitados círculos de intelectuais de espírito inconformista e perspectivas arejadas. como o eram os homens da conspiração "das hidras" e alguns dos da geração de 52 .

Figura que então se eleva é a de José Félix Henriques Nogueira, a quem devemos a primeira elaboração de um complexo doutrinal coerente e sistemático, durante muito tempo capaz de influenciar toda a actividade do republicanismo em Portugal. Podendo nós, por referência à textura social e política de então, assentar as suas propostas numa dimensão claramente utópica, esse "utopismo» era, para Henriques Nogueira, concretizável por uma prática progressiva, simultaneamente paciente e ousada, que o quimérico mas sedutor projesto "regenerador" condenaria ao isolamento.

A relativa prosperidade burguesa e monárquica que a «Regeneração", como inegável processo de modernização e de expansão económica, permitiu, não favorecia, entretanto, a acção generalizada contra um regime moderado, que poucos anteviam como obstáculo a ultrapassar. Será somente a partir de finais da década de 60 , justamente quando as propos-

$\left({ }^{5}\right)$ Joaquim de Carvalho, «Formação da ideologia republicana (1820-1880)», in Historia do Regimen Republicano em Portugal, ob. citada, tcmo I, p. 212.

${ }^{\circ}$ ) Veja-se José-Augusto França, $O$ romantismo em Portugal, vol. II, Lisboa, Livros Horizonte, 1977, p. 604; e ainda Daniel-Henri Pageaux, «Lamennais en Peninsule Iberique: notes sur la diffusion des idées mennaisiennes en Espagne et au Portugal (1834-1840)», in Utopie et Socialisme au Portugal au XIX Siècle. Actes du Coloque. Paris, 10-13 Janvier 1979, Paris, Fondation Calouste Gulbenkian - Centre Culturel Portugais, 1982, pp. 121-152. 


\section{O 1. Centenário Pombalino}

tas «regeneradoras» começam a perder o fôlego inicial, que se efectivará o grande impulso no avanço da organização e da propaganda republicana, apoiadas estas nas camadas sociais emergentes do desenvolvimento capitalista e excluídas do fechado sistema oligárquico dominante.

Sob uma aparente acalmia política, a juventude, sobretudo a de Coimbra, formada intelectualmente na descrença de muitos dos valores tradicionais, preparava-se para lançar no espírito público o gérmen de novos ideais e de novas inquietudes, que os ecos da situação externa (revolução espanhola iniciada em 1868, Comuna de Paris em 1871 e advento da República em França) ajudavam a incutir em crescentes camadas da população.

As propostas de Henriques Nogueira conquistam agora um novo sentido, sendo em torno das ideias fundamentais para as quais ele apontara-República, Socialismo e Federação - que, durante a década de 70 , se vão agitar as grandes dissidências e as mais entusiásticas formas de propaganda. Homens como Elias Garcia, Latino Coelho, Rodrigues de Freitas, José Falcão, Manuel Emídio Garcia, Teófilo Braga, e tantos outros, tiveram então (tal como mais tarde um Basílio Teles ou um Sampaio Bruno) uma importância fundamental na formulacão e na difusão do ideário republicano, precisando alguns dos seus pontos mais vagos, enriquecendo o seu conteúdo com elementos inteiramente novos, conferindo-lhe uma individualidade própria e um sentido actuante.

Manifestava-se assim a crença num progresso assente no cientismo e na razão positiva, justificado por um corpo doutrinal de base comteana (ainda que heterodoxa) e evolucionista que, conformado aos interesses específicos de uma vasta camada intermédia da sociedade portuguesa, definiria a trajectória futura do movimento republicano. Ao mesmo tempo, contra uma Igreia católica fundamentalmente antiliberal e passadista - e caldeado por aquela ideologia - o anticlericalismo tornava-se uma das suas bandeiras de luta $\left({ }^{10}\right)$.

Mas, para além do debate político e ideológico (ainda que em conformidade com este), a uniformização quase plena, conseguida em 1880, das várias tendências republicanas (que tinham sobrevivido à união formal de 1876), foi essen-

$\left({ }^{10}\right)$ Veja-se Fernando Catroga, «Os inícios do positivismo em Portugal. O seu significado político-social», in Revista de História das Ideias, vol. I, Coimbra, Instituto de História e Teoria das Ideias, 1977, pp. 287-394, e «A importância do positivismo na consolidação da ideologia republicana em Portugal», in Biblos. Revista da Faculdade de Letras, vol. LIII, Coimbra, 1977, pp. 285-327. 
cialmente possibilitada pela elaboração de uma estratégia política pragmática, maleável e combativa, assente na realidade de um país que o Partido Republicano, dada a sua base social, tinha, muito mais do que qualquer outra força política organizada, o ensejo de entender.

0 assumir do carácter interclassista, exterior à monarquia, das suas propostas políticas, conduziria então o Partido a afastar-se definitivamente dos socialistas, por longo tempo seus companheiros de jornada. Simultaneamente, passava a dar-se às reclamações um carácter estritamente político, de forma a que estas não pusessem em causa o processo de desenvolvimento económico e social vigente, mas tão só possibilitassem a correç̧ão dos seus excessos e assimetrias.

$\mathrm{Na}$ realidade, o aprofundamento do significado último do socialismo e da Comuna conduzirá, mesmo os republicanos mais radicais (e ressalvando raras excepções), a afastarem as quimeras socializantes herdadas de Henriques Nogueira e a colocarem-se do lado daqueles que privilegiavam a acção estritamente política. Tal como foi adoptado, em 1880 , o programa do Partido Republicano Unitário - que fora antes o da facção moderada de Elias Garcia - vai então cingir-se, exclusivamente, a reivindicações que se limitavam àquele domínio (igualdade civil e politica, liberdade em todas as suas manifestações, governo do povo pelo povo, justiça democrática). A partir desse momento, o republicanismo será, tão só, «um liberalismo reverdecido, que buscando incorporar uma mística patriótica, remoçando-a, concebe a ideia de um ressurgir da pátria portuguesa” ( $\left.{ }^{11}\right)$, o que se tornaria possível por alterações ao nível do regime. Esta atitude, se incompatibilizou com o Partido os seus elementos mais radicais, tornaria. no entanto, possível a sucessão dos êxitos.

Ao nível propagandístico, passa-se. pois, a exigir, não propriamente reformas estruturais de fundo (exceptuando, claro, o derrube da monarquia), mas a tomada de medidas como o estabelecimento de uma liberdade política formal, o saneamento da corrupcão que a dominância dos grandes grupos instalara, a institucionalização da igualdade de oportunidades e a secularização da sociedade (aqui especialmente no que diz respeito à imprescindível laicização do ensino e à defesa do registo civil obrigatório). E propõem-se também os republicanos assumir a patriótica missão de fazer sair Portugal da crescente decrepitude, em relação aos legados de um

(11) Joel Serrão, «Do socialismo ao republicanismo», in História, n. ${ }^{\circ}$, Lisboa, Public. «O Jornal», 1979, p. 14. 
passado que a maioria assumia como tesouros colectivos que importava resgatar.

Será esta política que vai permitir o engrossar constante das fileiras republicanas. As comemorações centenárias de $\mathrm{Ca}$ mões (1880) e do Marquês de Pombal (1882), tal como, mais tarde, o levantamento nacional em torno do ultimatum inglês de 1890 , constituirão momentos-chave desse prosesso evolutivo, no decurso dos quais um certo nacionalismo vai constituir o leitmotiv da propaganda do Partido. Procura-se, assim, de uma forma independente, o assumir dos valores tradicionais da pátria, identificando a monarquia, os partidos governamentais e os grandes grupos político-financeiros, com aqueles que se opunham à prossecução da inadiável tarefa de redenção nacional.

\section{Os socialistas}

Por esta altura, o acentuar das contradições entre os diversos grupos sociais e o consequente processo de diferenciação e de definição política, motivados que eram pela lógica de crescimento e de desenvolvimento do sistema, vai, pois, fazer perder ao republicanismo português o elemento socialista que antes contivera. A partir da década de 70, republicanos e socialistas terão percursos distintos: um reservado ao triunfo e o outro condenado a uma estagnação por longos anos prolongada.

A especificidade estrutural da sociedade portuguesa e o carácter serôdio do desenvolvimento do nosso socialismo estão na razão directa dessa situacão. Com efeito. enquanto os primórdios da revolução industrial permitem o lançar das sementes que conduzirão à situação revolucionária de 1848 e à sequente maioridade do movimento operário na generalidade dos países da Europa ocidental, em Portugal, a nascente Associação Promotora da Indústria Nacional, o Projecto de Associação para o Melhoramento das Classes Industriosas (da autoria de Silvestre Pinheiro Ferreira) e quase toda a produção teórica dos liberais, ainda que dos politicamente mais avançados, integram-se - como bem notou César de Oliveira - «na luta pelo desaparecimento dos laços corporativo-religiosos das indústrias e do trabalho» $\left.{ }^{\left({ }^{12}\right.}\right)$. Isto é, o reduzidís-

$\left.{ }^{(12}\right)$ César de Oliveira, O Socialismo em Portugal. 1850-1900. Contribuição para o estudo da filosofia política do socialismo em Portugal nr. segunda métade do século XIX, Porto, Afrontamento, 1973, p. 114. 


\section{O Marquês de Pombal}

simo operariado português tem então, como horizonte visível da sua acção - que outro não teria cabimento - a luta pela dissolução das estruturas laborais do "antigo regime». Compreenderemos melhor esta situação se recordarmos que, em 1852, data do primeiro Inquérito Industrial minimamente seguro, existiam em Portugal apenas 362 "fábricas» com mais de dez operários, a maioria delas muito pequenas e dispersas, empregando apenas 15897 pessoas (em cerca de três milhões e meio de habitantes) e 70 máquinas a vapor $\left({ }^{13}\right)$.

Será, assim, necessário esperar pelos tardios ecos do movimento de 48 e pelos primeiros passos da "Regeneração» para que, na década de 50 , se possa assistir, tanto no domínio da teoria como num plano organizativo, ao esboçar de uma corrente socializante autónoma, afastada porém do grupo social que mais propriamente a deveria enformar.

Este grupo, um operariado umbilicalmente ligado ao crescimento industrial, dava então os primeiros passos libertos dos estorvos corporativos, e de forma alguma tinha já, tomado globalmente, consciência do seu papel histórico como entidade autónoma. Por esse motivo, os primeiros passos seriam dados por uma juventude intelectual e funcionária, plasmada de um filantropismo romântico ou influenciada pelas ideias que chegavam de além-Pirinéus, mas, em ambos os casos, assumindo perspectivas que, mesmo tomando em linha de conta a especificidade da situação portuguesa, estavam longe de ser as de um operariado militante.

- Edco dos Operarios, publicado a partir de Abril de 1850 e dirigido pelos jovens Lopes de Mendonça e Sousa Brandão, desempenhará um papel pioneiro nesse processo. A designação operário aparecia, ela mesma, como inovadora, sabendo-se que, até finais da década de 60 , a maioria das publicações destinadas a esse sector social utilizavam ainda a designação de artista, com a conotação corporativa que esse termo naturalmente implicava.

Será a partir do círculo constituído em torno do Ecco que se formará a Associação dos Operários (1850), a qual, em 1852, dará lugar ao Centro Promotor dos Melhoramentos das Classes Laboriosas. Este servirá, até 1872, com base logística fundamental do associativismo operário.

Sob a capa protectora de políticos do liberalismo "regenerador» (como Rodrigo da Fonseca Magalhães, Rodrigues

(13) Veja-se Armando de Castro, A revolução industrial em Portugal no século XIX, 2." ed., Porto, Limiar, 1971, p. 28 ,e Ramiro da Costa, Elementos para a história do movimento operário em Portugal. 1820-1975, vol. 1.॰, Lisboa, Assírio \& Alvim, 1979, p. 17. 
Sampaio ou Casal Ribeiro), o Centro tornou-se, essencialmente, um instrumento dinamizador para a criação de associações de entreajuda e de instrução dos operários. Sousa Brandão, agora alto funcionário do Ministério fontista das Obras Públicas, redigirá os estatutos, logo aprovados pelo governo, e que garantirão a "apoliticidade» do Centro $\left({ }^{14}\right)$. Se, para além de Brandão, considerarmos as trajectórias políticas de Rodrigues Sampaio e de Casal Ribeiro, facilmente entenderemos como o Centro se tornara uma útil peça do projecto «regenerador" e veículo de subalternização e de dependência operária. A tal propósito, é deveras esclarecedor notar como esta «abertura" do Partido Regenerador encontra o seu equivalente no Partido Histórico (embrião do futuro Partido Progressista), o qual cria, em 1857, o Grémio Popular, com objectivos semelhantes aos do Centro $\left({ }^{15}\right)$, ainda que com menor impacto do que este.

Será por estes anos que, de uma forma independente, Félix Henriques Nogueira teoriza a aproximação de socialismo e republicanismo, num corpo doutrinal que não será temperado pela prática política de massas. Apesar da sua defesa do "socialismo", é essen zialmente no domínio da reorganização política da sociedade que se movem as propostas de Henriques Nogueira, entendendo ele poderem todas as restantes esferas do real por essa via serem atingidas. Por tal motivo, as suas propostas - defendendo a criação de um Estado republicano descentralizado e federado e a associação como forma de organização política e económica das populações aproximando-se embora do projecto que anos mais tarde, em França, Proudhon procuraria levar à prática, pouca influência tiveram na constituição de um socialismo nacional, enquanto se aproximavam das perspectivas republicanas.

A expressão característica da subalternidade do movimento operário português, entre a data de fundação do Centro Promotor e o princípio da intervenção da Associação Internacional dos Trabalhadores, será, essencialmente, o mutualismo, o associacionismo ligado à entreajuda e à instrução: os conflitos de trabalho são ainda raros e, como tal, facilmente liquidados pela intervenção governamental.

(14) Veja-se Costa Goodolphim, A Associação. Hisiória e desenvolvimento das Associações Portuguezas, Lisboa, Typ. Universal, 1376, pp. 113 e segs.

${ }_{\left({ }^{15}\right)}$ Veja-se Felizardo Lima, Resumo da história contemporânea do proletariado portuguez (1833 a 1897), Porto, Gutemberg, 1897, p. 42. 
Em Junho de 1871, após os acontecimentos da Comuna, viriam até Lisboa emissários da Internacional. Entrando em contacto com José Fontana, Antero e Batalha Reis, estes, depois com Eduardo Maia, Nobre França, Azedo Gneco e outros, constituirão o primeiro núcleo da Internacional em Lisboa. A sua acção inicial vai visar o Centro Promotor, procurando nele fazer aprovar novos estatutos, mais combativos e conformados aos interesses específicos dos operários, o que o go verno vai boicotar, não promulgando sequer esses estatutos. E então que, em 1872, se cria a autónoma Associação Fraternidade Operária, a qual, ainda que dividida pelos reflexos das querelas que internacionalmente opunham marxistas e bakuninistas e por questões internas de táctica política, constituiu o núcleo que conduziu em 1875, à fundação do Partido Operário Socialista, ao mesmo tempo que o crescimento industrial e a concentração operária permitiam as primeiras mo vimentações grevistas de monta.

O socialismo irompe, pois, em Portugal - como doutrina autónoma e coerente - na década de 70 , mas essencialmente por iniciativa estrangeira e apoiado em sectores restritos, mais emergentes dos ecos da política europeia do que de uma real evolução da sociedade portuguesa. Outra coisa não seria de esperar: mantinha-se o subdesenvolvimento da indústria nacional, revelado pelo Inquérito Industrial de 1881. Aí se computa em 90000 o número dos operários industriais (para uma população de quatro milhões e meio de habitantes), a maior parte dos quais distribuídos ainda por pequenas empresas, cujos instrumentos de producão somente agora começavam a superar o estádio artesanal ${ }^{(16)}$. Tal situação, tornava obviamente impossível o levantamento de um movimento operário poderoso e com uma real base de classe. Os resultados eleitorais do Partido Socialista e a representatividade das suas conferências e congressos traduzem, mais do que debilidades organizativas ou incorrecções de táctica política, essa realidade fundamental: a da inexistência de um operariado numeroso e adulto.

O Partido procuraria superar essa dificuldade congénita, desenvolvendo a sua actividade em áreas distintas: a económica, para a qual organiza a Associação dos Trabalhadores da Região Portuguesa, e a política, com a intervenção na discussão pública dos actos do governo, nomeadamente através da imprensa partidária, e a participação em eleições munici-

( $\left.{ }^{16}\right)$ Veja-se Ramiro da Costa, $O$ desenvolvimento do capitalismo em Portugal, Lisboa, Assírio \& Alvim, 1975, p. 24. 
pais e para a Câmara de deputados $\left({ }^{17}\right)$. Será, porém, a discussão em torno dos processos tácticos de combinar tais modalidades, bem como a repercussão das grandes polémicas que então dividiam o movimento operário europeu, que, a breve trecho, conduzirão o Partido a cisões e a um progressivo apagamento político.

Reformistas (sempre maioritários), colectivistas e anarquistas, bater-se-ão, dentro do Partido ou em polémica com ele, até que cada uma das diversas tendências siga o seu próprio caminho. Ao mesmo tempo, a incapacidade, demonstrada pelos socialistas, para construírem um projecto político e social que se distinguisse do republicano e positivista, constitui um dado obstruidor, que a própria imprensa partidária atesta. O Protesto Operário, órgão do Partido, escreve, em 1882: "A revolução natural é o produto da evolução, como esta é, por seu turno, o resultado da revolução do pensamento, da acção de necessidades novas, logo traduzidas na aspiração evolutiva e continuada de uma determinada adaptação do meio social a essas tais aspirações e necessidades. Fora disto há a perturbação, a desordem, o sobressalto, impedindo o caminhar natural das sociedades. Revolucionário não é o que inesperadamente puxa o fuzil, afirmando as suas crenças por entre o suspirar das batalhas. Revolucionário é o que atira para o mundo pensador com novas teorias, manifestacões ou inventos, alterando o quietismo social pela criação de horizontes novos" $\left({ }^{18}\right)$.

Os socialistas manter-se-ão então, por muito tempo, e é essa a situação na década de 80 , numa grupuscular situação de subalternidade em relação ao republicanismo, numa posição de seguidismo político e ideológico que a direcção partidária reformista não saberá - ou não poderá - ultrapassar.

\section{A aç̧ão maçónica}

Mas este breve quadro da vida política portuguesa dos inícios do último quartel do século XIX mostrar-se-ia limitado se não ponderássemos o destacado papel desempenhado pela maçonaria ou pelos seus membros. E certo que, dada a carência de fontes documentais seguras e minimamente imparciais, o trabalho do historiador é aqui particularmente di-

(i7) Veja-se César de Oliveira, ob. cit., pp. 154-155.

(18) Luís de Figueiredo, «Evolução ou revolução», in O Protesto Operário, órgão do Partido Operário Socialista, Lisboa-Porto, n. ${ }^{\circ} 42,17$ de Dezembro de 1882. 
fícil e moroso. Não poderemos, todavia, ainda que de uma forma sucinta e provisória, deixar de considerar alguns aspectos.

O ideário maçónico é complexo e não sistemático. Não possuindo a maçonaria leis gerais ou "livro santo" que lhe definam os cânones e obriguem todo o mação a uma prática específica, não existe por isso, no seu interior, uma absoluta unidade de vontade, que imponha aos seus membros uma conduta homogénea. Existe sim um conjunto de princípios fundamentais, aceites por todos os irmãos e em todas as partes, e que funcionam afinal como cimento da unidade e da vitalidade da Ordem.

Tais princípios mergulham as suas raízes no espaço mental do deísmo e do filantropismo, emergentes do "século das luzes", no decurso do qual se formou e desenvolveu a moderna maçonaria. Lembre-se, tão só, que na simbologia maçónica - como na dos iluminados - é o Sol um dos emblemas mais significativos, como fonte de um inesgotável manacial de vida e de luz, representando o seu aparente movimento celeste o eterno combate entre o bem e o mal, a Luz e as Trevas $\left({ }^{19}\right)$.

Será dessa postura cultural que brotarão os princípios de Justiça e de Solidariedade humanas, e, em consequência, os da Democracia e da Igualdade políticas, os quais, conjuntamente com o culto do aprofundamento de um mítico Saber que se pretende universal, orientarão a acção cosmopolita da maçonaria a partir dos meados de Setecentos.

Por tudo isto. torna-se subjectivamente impossível, num primeiro olhar, a filiação maçónica de autoritários e conservadores. Porém. o secretismo organizativo e os deveres de entreajuda irão, em muitos casos, proporcionar vantagens que compensam bem condescendências de prin_ínios. Além disso, o carácter vago e subiectivo do ideário macónico, assente em genéricas conceptualizacñes. que a nartir da Revolução Francesa se foram esvaziando de sentido. acabará por conduzir a atitudes práticas diversificadas, não raro contraditórias. Nesta medida, não se estranhará o denarar, no curso da história europeia dos últimos três séculos, com maçãos posicionados em quadrantes doutrinais e nolíticos divergentes.

Torna-se assim extremamente polémica toda a tentativa de caracterizar a vida da maçonaria, no nosso país, como

(19) Veja-se Joaquim Gervásio de Figueiredo, Dicionário da Maçonaria, São Paulo, Editora Pensamento, 1970, p. 458, e Georges Gusdorf, Les principes de la pensée au siècle des lumières, Paris, Payot, 1971, pp. 293-309 e 402-413. 
constantemente actuante e progressiva, tal como de ordinário tem sido feito. Particularmente para os maçãos liberais ou republicanos do século XIX, seria bastante sedutore politicamente conveniente - identificar, de uma forma abusiva, o "espírito maçónico" com posições de vanguarda política e cultural, emergentes da sociedade portuguesa do século XVIII e dos inícios do século seguinte. A investigação histórica recente parece, porém, apontar para conclusões diferentes, especialmente no que se refere aos periodos pombalismo e mariano $\left({ }^{20}\right)$. Pela nossa parte, cremos ser lícito aproximar, com segurança, a acção da maçonaria a atitudes de vanguarda presentes na nossa sociedade, somente a partir de finais do século XIX, quando a Ordem se liga, de uma forma clara, ao crescente movimento republicano. Até aí, a velha tendência burguesa e jacobina, que, depois de 1820 , o maçonismo de origem francesa imporá em Portugal - numa altura em que a obediência inglesa já pouco mais executava do que a prática dos ritos e obras de entreajuda e beneficência - será, por muito tempo, temperada pelo carácter atrasado e oligárquico do nosso capitalismo caseiro, com todas as consequências políticas e ideológicas que esta situação compreensivelmente acarretava.

Ressalvando um curto período, imediatamente após 1820 , a maçonaria portuguesa (sobretudo o maioritário Grande Oriente Lusitano) assumirá, por muito tempo, uma posicão essencialmente conservadora, ainda que conforme às tendências dominantes da vida nacional. Liga-se, assim, ao cartismo (Costa Cabral foi seu grão-mestre de 1841 a 1848), o que originaria sucessivas desinteligências. Cisões diversas se foram então instituindo, transformando-se as respectivas lojas, como afirma Oliveira Marques, em "verdadeiros sovietes de decisões políticas a nível nacional" ( $\left.{ }^{21}\right)$ : para além dos ideais humanitários, erguia-se agora a estratégia dos partidos.

Entre 1849 e 1869 coexistirão então, em Portugal, obediências maçónicas distintas, na direç̧ão das quais sobressairão nomes como, para além do já referido Costa Cabral, os de Saldanha, Passos Manuel e Rodrigues Sampaio (estreitamente vinculados aos partidos monárquicos), do liberal "radical» José Estevão e de Elias Garcia, com a Federação Maçónica, ligando-se esta à tendência não monárquica que, de futuro, irá hegemonizar a maçonaria portuguesa.

$\left({ }^{20}\right)$ Veja-se Graça e J. S. da Silva Dias, Os primórdios da maçonaria em Portugal, 4 tomos, Lisboa, I.N.I.C., 1980.

(") A. H. de Oliveira Marques, $A$ Maçonaria Portuguesa e o Estado Novo, Lisboa, Public. Dom Quixote, 1975, p. 44. 
Esses distintos Orientes, para Borges Grainha fundados a partir dos diversos grupos presentes na emigração de $28\left({ }^{22}\right)$, fundir-se-ão, em 1869, no Grande Oriente Lusitano Unido, elegendo como grão-mestre o conde de Paraty, ex-governador civil de Lisboa, par do Reino e membro de uma das mais importantes casas da nobreza. A partir desse momento-e até aos nossos dias - foi possível manter unida a família maçónica, se deixarmos de lado cisões limitadas e pouco duradouras $\left({ }^{23}\right)$.

O emergente conflito entre aqueles que, como Paraty, pugnavam por uma maçonaria "pura» e "apolítica», e os maçãos mais radicais, que procuravam já transformar a Ordem num instrumento de combate à "reacção», ir-se-á resolvendo, gradualmente, através da evolução interna desta. A tal não será por certo estranho o afluxo de sectores importantes da intelectualidade, empenhados estes num processo de ruptura com o regime.

Mas até finais do século, quando se afirma como irreversível a aproximação do Grande Oriente ao Partido Republicano, por muito tempo se manterão, ligados à Ordem, homens que se situam desde os partidos monárquicos até aos socialistas. Em 1882, portanto, a maçonaria portuguesa contém ainda, no seu seio, um vasto leque político; por tal motivo, é essencialmente o seu carácter liberal e anticlerical que nos importa reter, por serem esses os traços fundamentais e unificantes do empenhamento cívico dos seus membros.

Mas não será somente a sua opção racionalista e arreligiosa que empurrará a maçonaria para uma frontal postura de combate ao absolutismo monárquico e à maioria do clero católico. $\mathbf{O}$ antiliberalismo como posição oficial do papado - num retomar das velhas concepções tomistas que o Concílio Vaticano I (1869) procurará fazer renascer -e a tentativa de, sobretudo através da actividade dos iesuítas, se organizar uma oposição católica ao poder rotativista e à gradual laicização do ensino, levarão a Ordem, 'favorecida aqui pelas suas características organizativas e pela sua composição, ao combate anticlerical. A campanha a favor do registo civil obrigatório (procurando retirar aos párocos o "po-

$\left.{ }^{22}\right)$ M. Borges Grainha, História da Franco-Maçonaria em Portugal. 1733-1912, Lisboa, Typ. A Editora, 1913; consultada a 2. ed., Lisboa, Ed. Vega, 1976, p. 125.

$\left.{ }^{23}\right)$ Pela sua importância para o nosso estudo, destacamos a cisão de 1882-84, da Grande Loja Simbólica de Portugal, a qual terá, como grão-mestre, José Dias Ferreira, então considerado um liberal situado à margem dos partidos rotativistas. 
der local»), as sucessivas reformas liberais do sistema de ensino, a tentativa de construção de uma igreja nacional relativamente distanciada de Roma, constituirão então iniciativas governamentais às quais a maçonaria dará todo o seu apoio e disponibilidade militante. A condenação da Ordem pelo papa Leão XIII, em 1884, retomando aliás argumentos de antecessores seus, não irá senão acentuar esse movimento.

$A$ «questão religiosa»

De facto, o posicionamento político da Igreja romana e dos católicos portugueses desempenha um papel fundamental na evolução da política nacional da segunda metade do século XIX.

E inegável a aproximação dessa Igreja ao poder político e à cultura dominante na época pré-liberal da Europa não reformada. Desde Trento que a sua aposta consistira numa ligação estreita ao gládio temporal e aos valores tradicionais, na crença de ser essa a forma de assegurar a sua existência e a exequibilidade da sua missão.

A explosão liberal dos princípios do novo século veio introduzir alterações na precaridade desse equilíbrio, então destruído: os laços de Roma com o apeado absolutismo conduziriam agora, tanto uma das partes como a outra, a um inevitável distanciamento. $\mathrm{E}$, em vez de rever a sua posição, conformando-a às novas realidades da sociedade liberal $e$ industrialista, o papado vai, por muito tempo, remeter-se à firme defesa de forças e de valores que íam sendo apagados pela História.

A atitude corajosa e pioneira de um Lammenais e dos seus companheiros de L'Avenir (que se publicava sob a epígrafe Deus e Liberdade; o Papa e o Povo), propondo o repensar da acção política e social da Igreja, no contexto de um "liberalismo católico» que separasse essa Igreja do Estado $\mathrm{e}$ atendesse às realidades sociais dos novos tempos $\left({ }^{24}\right)$, Gregório XVI responde com a encíclica Mirari vos (1832), na qual se condenava aquela publicação, estigmatizando a liberdade de imprensa com os epítetos de "funesta», "odiosa» e "execrável», e se afirmava ser a liberdade de consciência "fonte infecta de indiferentismo" $\left({ }^{25}\right)$.

(24) Veja-se Adrien Dansette, Histoire religieuse de la France contemporaine. L'Église catholique dans la mêlée politique et sociale, Paris, Flammarion, 1965, pp. 223-241.

${ }_{\left({ }^{25}\right)}$ Veja-se Sampaio Bruno, $A$ questão religiosa, Porto, Livr. Chardron, 1907, st. pp. 1-161. 
Por muitos anos, a postura oficial da Igreja, em relação aos princípios fundamentais do liberalismo, será, pois, a de uma oposição frontal. A encíclica Quanta cura (1864), de Pio IX - um papa inicialmente tido por "liberal", que os acontecimentos de 48 ajudariam a empurrar para a intransigência $\left({ }^{28}\right)$-e o Syllabus, "catálogo dos erros do nosso tempo", virão tão só reforçar essa tendência. $\mathrm{Na}$ proposição 80." do Syllabus - que o nosso Antero estigmatizará num artigo mordaz $\left({ }^{27}\right)$ - pode ler-se a condenação de todo aquele que afirmar que «o Pontífice romano pode e deve reconciliar-se com o progresso, com o liberalismo e com a civilização moderna" ${ }^{(28)}$, sendo, ao longo do texto, igualmente anatematizados a laicidade do Estado, a liberdade de imprensa, a soberania do povo ou a negação do direito de a Igreja católica dirigir a educação da juventude. 0 mesmo papa convocará, aliás, o Concílio Vaticano $\mathrm{I}$, no qual se definirá o dogma da infalibilidade papal, esse "privilégio sobrenatural, transmitido por Jesus Cristo a todo o papa na pessoa de Pedro, de não errar jamais, quando, falando livremente ex cathedra, como doutor da Igreja universal, ele define uma doutrina relativamente à fé e aos costumes» $\left({ }^{29}\right)$.

A acção do sucessor de Pio IX, o papa Leão XIII, por vezes considerado também um "liberal" (foi sob o seu pontificado que se lançaram as bases da "democracia cristã», como corrente autónoma de opinião e de acção política e social, e se publicou, em 1891, a encíclica Rerum novarum, especialmente destinada à "questão social»), marcará, no essencial, mais o reconhecimento formal de uma realidade irrecusável e a consciência da necessidade de aceitar as "regras do jogo" político, do que, propriamente, uma afirmação de fé liberal e uma alteração da posição oficial de Roma face às realidades do seu tempo $\left({ }^{30}\right)$. A atitude intolerante do novo pontífice

$\left({ }^{20}\right)$ Veja-se Adrien Dansette, ob. cit., pp. 268-280.

("7) Veja-se Antero de Quental, «Defesa da carta encíclica de Sua Santidade Pio IX contra a chamada opinião liberal», in Prosas da Epoca de Coimbra, Lisboa, Sá da Costa, 1975, pp. 205-226.

$\left({ }^{28}\right)$ Veja-se J. F. Trindade Coelho, ob. cit., p. 627.

(\$) Referido por A. Dansette, ob. cit., p. 323. Veja-se ainda Fernanda Farinha Nogueira, O Concílio do Vaticano I. Sua Projecção em Portugal à luz da Imprensa Católica Portuguesa e da Correspondência Oficial, dissertação de Licenciatura em História apresentada à Faculdade de Letras de Coimbra, Coimbra, 1970.

${ }^{\left({ }^{\circ}\right)}$ ) João Francisco de Almeida Policarpo, $O$ pensamento do grupo católico de «A Palavra» (1872-1913), vol. I, Coimbra, Centro de História da Universidade de Coimbra, 1977, p. 24. 
face ao socialismo, é elucidativa dos limites da sua «abertura" ( $\left.{ }^{81}\right)$.

Torna-se, nesta medida, perfeitamente óbvio que essa intransigência, nos princípios e nos actos, venha a acarretar a animosidade dos liberais e a suscitar o anticlericalismo.

Assim, em Portugal, cedo personalidades católicas de meios políticos e literários não tradicionalistas, como Garrett, Castilho, Herculano, João Maria Nogueira, o bispo D. António Alves Martins, Rodrigues Sampaio ou mesmo Henriques Nogueira, passaram a exprimir a sua simpatia pelas ideias de Lammenais $\left({ }^{32}\right)$, opondo-se abertamente ao ultramontanismo antiliberal, dominante entre o nosso clero. A opção política fundamental da hierarquia católica vai, então, exprimir-se numa ligação nítida ao legitimismo miguelino. Sucessivos governos ver-se-ão, por tal motivo, forçados a intervir em assuntos de natureza religiosa, criando situações de incompatibilidade com as atitudes papais e provocando medidas constrangedoras da actividade eclesiástica, como o testemunha a acção dura e exemplar de Joaquim António de Aguiar. As concordatas de 1848,1857 e 1886 , serão mesmo compelidas a reconhecer à coroa portuguesa algum poder de intervenção na condução dos assuntos católicos.

A "questão religiosa», que se coloca então em Portugal. será, sobretudo, como nota Manuel Braga da Cruz, "uma questão de liberdade religiosa para a Igreja, que não abandonará, porém, veleitárias pretensões de reaquisição das velhas condições de proteccionismo social, de reapropriação ou indemnização das suas perdas materiais e de revogação das leis anticongregacionistas", o que dividirá os católicos portugueses: "por um lado, os católicos legitimistas, cujo integralismo e conservadorismo os levam a não dissosiar o religioso do político...., por outro lado, os católicos constitucionalistas, que aceitavam mover-se dentro do estado de coisas político liberal, respeitando as autoridades revolucionariamente constituídas» $\left.{ }^{(33}\right)$.

Mas a irredutível, ainda que limitada, oposição legitimista ao regime, manifestava-se incapaz de satisfazer as reivindicações católicas de liberdade religiosa e de impedir as

${ }^{(31}$ ) Veja-se Victor Manuel Arbeloa, Socialismo y anticlericalismo, Madrid, Taurus, 1973, pp. 16-19.

${ }^{\left({ }^{32}\right)}$ Veja-se Carlos da Fonseca, História do movimento operário e das ideias socialistas em Portugal. III - O operariado e a Igreja militante, Lisboa, Europa-América, 1981, pp. 59-67.

${ }^{(3)}$ Manuel Braga da Cruz, As origens da Democracia Cristã e o salazarismo, Lisboa, Presença-G.I.S., 1980, pp. 58-59. 
constantes intromissões do poder político nos assuntos da Igreja. Tal situação conduziu um importante sector do mundo católico à percepção de que só a partir de uma actuação dentro do sistema vigente seria possível retomar o terreno perdido. Com Leão XIII, essa tendência passa a exprimir-se mais abertamente, "diferenciando no liberalismo a ideologia do sistema político, para, de acordo com as instruções romanas, repudiar a primeira e acatar, de facto o segundo» $\left({ }^{34}\right)$. Esses católicos irão então ensaiar formas de organização e de intervenção, que visavam pôr termo à letargia do movimento católico e combater pelas suas reivindicações.

Esta é, pois, a situação que, face à política e às ideologias, a Igreja católica vive entre nós, em finais da década de 70 do século passado. Manifestando-se separadamente, as duas tendências - sendo a legitimista sempre dominante aproximar-se-ão na luta comum contra a maçonaria, o republicanismo, o socialismo e os partidos monárquicos laicos, "culpados" todos eles, como veremos, de combaterem ou procurarem limitar a influência clerical.

Assim se começa a constituir a ideia de formar em Portugal um partido católico, que permitisse superar o impasse político em que se encontravam os católicos legitimistas e apontasse para uma maior participação dos católicos «liberais» na condução dos destinos do país. Será com esse propósito que se formará, em 1882, a União Católica Portuguesa, a qual, logo no artigo $1 .^{\circ}$ do seu programa, aponta, como seu objectivo primordial, "promover a sólida união de todos os católicos portugueses, a fim de assim melhor se conhecerem, de se fortalecerem nas suas crenças cristãs, de se auxiliarem reciprocamente na prática do bem.... e de defenderem por todos os meios lícitos e legais, mas principalmente pela apresentação de deputados católicos no parlamento português, os elevados interesses da causa católica, como base fundamental dos mesmos interesses morais e sociais do país» $\left({ }^{35}\right)$.

Tinha sido já nesse sentido que, no Porto, se tinha constituído o grupo católico que, a partir de 1872, iria publicar A Palavra. Mas é somente com a vinda para Portugal do novo núncio papal, o cardeal Mazella, que, sob a inspiração directa de Leão XIII (de quem Mazella era colaborador directo, tendo inclusivamente sido, mais tarde, um dos redactores da

(24) Manuel Braga da Cruz, «Os católicos e a política nos finais do século XIX», in Análise Social, vol. XVI, n. ${ }^{\circ} 61-62$, Lisboa, Gabinete de Investigações Sociais, 1980, p. 261.

${ }^{20}$ ) O Progresso Catholico, Guimarães, n. $19,4 .^{\circ}$ ano, 30 de Julho de 1882, p. 226. 
Rerum novarum), a acção católica, no domínio político, vai tomar um novo impulso.

Chegado ao nosso país em 1879, a sua missão é então anunciada pelo jornal Italie nos seguintes termos: «Monsenhor Aloizi Mazella, novo núncio apostólico em Portugal, partirá dentro de alguns dias para Lisboa, onde, como monsenhor Czacki em Paris, vai desempenhar uma missão muito delicada. Efectivamente, há algum tempo que em Portugal, no seio do Parlamento e fora dele, se debatem questões político-religiosas. Uma das questões mais importantes é, sem a menor dúvida, a que diz respeito ao casamento civil, que os legisladores querem introduzir em Portugal" $\left({ }^{38}\right)$. Recorde-se aqui - e voltaremos ao assunto - que Czacki tinha ido para Paris por alturas do início da actividade de Jules Ferry como ministro da Instrução Pública francesa.

Mazella iria tentar começar por conseguir que fosse o papa, e não o ministro da Justiça, como até então, o fora a nomear os novos bispos para as diversas dioceses que entretanto tinham vagado. Será derrotado. $\mathrm{O}$ ministro da Justiça, Júlio de Vilhena, escreverá anos mais tarde, referindo-se a Mazella e a este caso: "Ele queria lançar as bases do partido católico que até então não tinha existido em Portugal, e achava excelente ocasião para que fossem colocados nos lugares vagos homens de ideias reaccionárias, de preferência aos meus candidatos, conhecidos pelo seu espírito liberal e tolerante» $\left({ }^{37}\right)$. A intransigência de Vilhena - membro destacado do Partido Regenerador - conduzirá à expulsão do núncio, e será tão elogiada pelos partidos monárquicos, decerto tementes da formação de uma força política capaz de abalar a precaridade da sua situação, como, naturalmente, pelos republicanos.

Por esta altura, e tratando a questão, um opúsculo católico anónimo porá, a seu modo, o dedo na ferida: "Não é um ataque pessoal, posto aue assim o pareca, mas uma questão de prinsípios: é o batalhar entre instituicões que de longa data se combatem e guerreiam, o duelo interminável entre religião e impiedade, entre a Igreja e a maçonaria. E, enfim, a questão do predomínio da sociedade: ou governá-la com as leis cristãs, ou dominá-la pelos princípios do liberalismon ${ }^{\left({ }^{38}\right)}$.

( $\left.{ }^{36}\right)$ Veja-se Júlio de Vilhena, Antes da República, vol. I (Suplemento), Coimbra, França \& Arménio, 1918, pp. 253-254.

(अ) Idem, vol. I, 1916, p. 106.

(') $O$ Núncio e a Maçonaria, ou resposta dada à imprensa liberal às accusaçōes feitas contra Monsenhor Mazella, Nuncio de S. Santidade em Lisboa. Por um padre catholico verdadeiramente amante da sua patria, Lisboa, Livraria Catholica, 1882, pp. 3-4. 


\section{A laicização da sociedade}

Ressalvando a natural parcialidade do juízo, a questão que se punha era precisamente essa. Se até ao advento do liberalismo político, a íntima e tradicional união da Igreja e da Monarquia não impedira a soberania real de reivindicar os seus direitos e privilégios, sem recuar perante um eventual conflito com o papado, a nova situação era bastante mais susceptível de conduzir - tal como determinados momentos aconteceu - à ruptura, agora possível também numa base ideológica, logo mais profunda. De um lado, a hierarquia católica dominante mantinha-se, como vimos, firme na defesa dos valores tradicionais e dos seus interesses no mundo temporal. Mais além, um mundo em crescimento e ebulição engendrava formas novas de relacionamento do indivíduo com o meio e com os outros, num igualitarismo político que a realidade material de há muito ía mesclando. 0 abismo entre a Igreja católica e a sociedade civil ía, pois, aumentando de uma forma contínua.

Essa Igreja constituía, todavia, uma força ainda poderosa, dotada de uma vitalidade própria e capaz de moldar a visão do mundo e o comportamento ético e social de parte importante do ocidente. No púlpito ou no ensino, como no controlo de grande parte da assistência pública ou no lugar privilegiado que os meios rurais lhe concediam, a influência clerical, fiel a Roma, seguia combatendo o regime demoliberal, tendencialmente utilitário e cientista, que, no meio de convulsões várias, continuava a reformulação das estruturas mentais e pedagógicas da velha sociedade.

$O$ caso francês tipifica esse movimento, interessando-nos especialmente pela constante referência paradigmática que, sobretudo no século XIX, lhe faz a élite política e cultural do nosso país.

A derrota das tentativas de desenvolvimento de um catolicismo liberal e o triunfo do ultramontanismo coincidira, em França, com uma situação política de viragem. Durante a guerra franco-prussiana, a queda de Napoleão III dera lugar ao advento da Terceira República. Entre 1871 e 1879, Thiers e Mac-Mahon presidirão então a governos de pendor essencialmente conservador, aos quais sucederá a presidência «centrista» de Jules Grévy (1879-87).

Por essa época, e pela primeira vez desde o século XVIII, a irreligiosidade apossava-se dos grupos dominantes da sociedade francesa. A tal situação não seria estranha, como vimos, a intransigência antiliberal da Igreja romana. Mas a origem desta tendência é detectável a dois outros níveis. 


\section{O 1. Centenário Pombalino}

Antes de mais, o Segundo Império permitira a expansão dos grupos económicos e da grande burguesia industrial e financeira. Capitalismo e industrialização em grande escala caracterizaram então os anos que viram nascer os sonhos de Júlio Verne. Mas, no plano social, esse crescimento implicava, a par da formação de um importante proletariado, o rápido desenvolvimento de um sector intermediário, ligado ao boom do sector dos serviços e do comércio interno. Este grupo, tinha, naturalmente, interesses sociais e políticos que o distinguiam dos grupos dominantes e que o republicanismo menos conservador corporizará.

Por outro lado, a expansão do espírito positivista - que Littré saberá depurar dos "irrealismos» comteanos e adaptar aos interesses das classes médias - e o vigoroso impulso sentido no campo das ciências físicas e naturais, traduzido nas sistematizações teóricas utilitárias e evolucionistas, irão fornecer às forças em ascensão os instrumentos teóricos necessários para a elaboração de uma mundividência própria e de um projecto político unificante e mobilizador.

O anticlericalismo constituirá então um dos elementos dessa tendência. Em 1863, Ernest Renan publicava $A$ Vida de Jesus, cujas edições se multiplicarão rapidamente. Em 1867, na sua tese de doutoramento, Clemenceau, eliminando a ideia de criação, admitia «a heterogeneidade dos seres por via das forças naturais imanentes à matéria» $\left({ }^{30}\right)$. Homens políticos, filósofos, pedagogos, professores, abraçam o ideal laico como a uma fé que entendem libertadora e criativa. E então que partem ao assalto das fortalezas da credulidade e do poderio católico.

Jules Ferry torna-se, em 1879, ministro da Instrução Pública. Será presidente do Conselho até Novembro de 1881 e depois, uma segunda vez, entre 1883 e 1885. Positivista e mação $\left({ }^{40}\right)$, a sua acção governativa consubstanciará, na prática, as tendências laicizantes e as preocupações pedagógicas do republicanismo francês, impondo medidas revolucionárias como a gratuitidade, laicidade e obrigatoriedade do ensino primário, a dissolução de grande parte das congregações religiosas (com os jesuítas à cabeça), a multiplicação das escolas para pro-

${ }^{\left({ }^{30}\right)}$ Referido por Louis Capéran, Histoire Contemporaine de la Laïcité Française. La crise de seize Mai et la revanche republicaine, Paris, Marcel Rivière, 1957, p. XIX.

$\left({ }^{*}\right)$ Veja-se Alec Mellor, Histoire de l'anticléricalisme français, Paris, Mame, 1966, pp. 318-329, e Louis Capéran, ob. cit., pp. 1-12. 
fessores que irão substituir os membros do clero na instrução oficial ou a fundação do ensino secundário para raparigas.

Entretanto, em Portugal, a Igreja controlava também parte importante do aparelho educativo. Em 1864, havia 4108 padres e vigários para 2445 professores, enquanto, em 1873, havia 1816 seminaristas contra cerca de 6000 alunos inscritos em todos os liceus do país $\left.{ }^{(11}\right)$. Nesta mesma data, em Coimbra, licenciavam-se ainda mais estudantes em Teologia do que em Medicina $\left({ }^{42}\right)$. Ao mesmo tempo, as diversas congregações - tendo os jesuítas como élite destacada - voltavam paulatinamente a instalar-se no país e a tomar nas suas mãos parte importante do ensino e da assistência $\left({ }^{49}\right)$.

Também entre nós os representantes do tradicionalismo, tanto em matéria religiosa como em matéria social e política, viam nessa situação um campo de combate à sociedade liberal e à invasão do cientismo. Inversamente, os liberais de todas as categorias olhavam com desagrado tal posição, e homens como Fontes Pereira de Melo, Anselmo Braamcamp, Rodrigues Sampaio ou José Luciano de Castro tomarão medidas, tímidas embora, no sentido de alterar esse estado de coisas. A reforma de 1880 de José Luciano seria, aliás, de todas quantas vigoraram no século XIX, a que mais se aproximaria dos ideais positivistas e spencerianos, que os círculos pensantes das camadas dirigentes da nossa sociedade íam também adoptando. Referente ao ensino secundário, tal reforma propunha-se "difundir os conhecimentos gerais indispensáveis para todas as carreiras e situações sociais", ou seja, preparar para a "vida prática», como o queriam os defensores da instrução científica e utilitária e carecia o sistema económico imperante $\left(^{44}\right)$. Esse movimento era, todavia, obstruído pela postura clerical, o que virá a inevitabilizar o conflito.

Os republicanos, associando-se de há muito a essas reivindicacões laicistas, pretendiam, naturalmente, ir mais longe. $\mathrm{Na}$ verdade, a influência clerical sobre as consciências repre-

p. ${ }^{\left({ }^{2}\right)}$ Veja-se Joel Serrão, «Elementos para o estudo da instrução pública em Portugal, cerca de 1870», in Labor, Aveiro, n..$^{\circ} 113$, ano XV, Maio de 1951, p. 186.

('3) Mau grado o seu sectarismo, veja-se, pela abundância dé elementos que contém, Manuel Borges Grainha, História do Colégio de Campolide da Companhia de Jesus escrita em Latim pelos Padres uo mesmo Colégio onde foi encontrado o Manuscrito, Coimbra, Imprensa da Universidade, 1913.

${ }^{\left({ }^{4}\right)}$ Veja-se Vasco Pulido Valente, O Estado liberal e o Ensino, Os Liceus Portugueses (1834-1930), Lisboa, Gabinete de Investigações Sociais, 1973, pp. 51-56. 
sentava, pelas suas características antiliberais e opostas ao progresso científico que se vivia, um obstáculo político-ideológico que importava ultrapassar. Assim, se a táctica republicana visava a formação e o apoio da opinião pública, a Igreja, dado o seu posicionamento político e o suporte que lhe era dado pelas forças sociais tradicionais e conservadoras, constituía um dos principais alvos da sua propaganda $\left({ }^{45}\right)$. $\mathrm{O}$ anticongreganismo (especialmente o antijesuitismo), a luta pela laicização do ensino e das mentalidades, a tentativa de levantạmento de uma assistência não ligada à Igreja, a campanha a favor do registo civil obrigatório, constituirão então reivindicações e atitudes políticas fundamentais.

O centenário pombalino, tal como, anos depois, a homenagem pública à memória de Joaquim António de Aguiar, constituirão momentos privilegiados - dadas as características da acção política das figuras lembradas - da materialização dessa luta por uma sociedade laica e republicana.

\section{O SIGNIFICADO DO CENTENARIO}

\section{A justificação positivista}

Foram pois os republicanos quem mais se empenhou na efectivação e no brilho do centenário. Mas não o fizeram somente motivados por uma inteligente apreensão dos dividendos políticos que daí poderiam retirar-fizeram no também por uma questão de princípio. As comemorações, não só constituíam, para eles, ocasiões de vir a terreiro propagandear as suas ideias, como representavam ainda um acto necessário, vital mesmo, justificado pela sua inserção num corpo doutrinal mais vasto.

Um positivismo modulado pelas concepções littreanas e spenserianas e pela producão teórica de homens como Teófilo Braga ou Manuel Emídio Garcia, cornorizava a principal teoria formadora e unificante do republicanismo português. armando-o para a compreensão do movimento geral da sociedade e do seu papel nesse movimento com conceitos precisos, que se destacavam dos velhos lugares-comuns do liberalismo. Uma inteleccão "científica", positiva, da marcha da sociedade e da política portuguesa permitiria, assim, apontar para uma evolução da sociedade que conduziria inevitavelmen-

( ${ }^{45}$ ) Veja-se Fernando Catroga, «A importância do positivismo...», ob. cit., pp. 310-311. 
te à almejada república, devendo esse movimento ser encamizhado pela via de um justo equilíbrio entre ordem (isto é, a manutenção daquilo que se entendia serem conquistas do género humano e salvaguardar) e progresso (ou seja, a correcção das taras herdadas das fases teológica e metafísica da evolução da humanidade). 0 positivismo surge então, simultaneamente, como teoria de conservação e de mudança, servindo eficazmente as aspirações do grupo social intermédio que era a seiva do Partido Republicano.

Será, pois, numa leitura muito própria da obra de Augusto Comte, temperada por contribuições teóricas posteriores, que a maioria dos intelectuais republicanos irá radicar a justificação ideal da sua acção política $\left({ }^{(6)}\right)$. A importância que o Partido dará às comemorações centenárias, para além de se entender, como foi dito, no quadro de um aproveitamento táctico de sentimentos "nacionalistas» e de redenção dos valores pátrios que uma grande parte da população assumia, ficará também a dever-se à conceptualização positivista acerca do papel histórico dos grandes homens e da sua evocação.

A sociolatria do Comte do Système de Politique Positive e do Cathéchisme Positiviste, com a proposta da constituição de uma Religião da Humanidade, dirigida por uma casta organizada (os sociólogos positivistas), dotada de um culto e dos seus santos (os grandes homens), capaz de orientar o género humano na sua vida em sociedade e na sua missão histórica, não vai, sob essa forma ortodoxa, encontrar eco em Portugal. Aqui, a elaboração de uma concepção do mundo capaz de assegurar o progresso e de manter uma certa ordem irá ser procurada, pelos republicanos positivistas, de um modo pragmático, pela formação de uma opinião pública coesa e clarividente $\left({ }^{47}\right)$.

Escrevera Comte, ainda no Cours de Philosophie Positive, que "les grands progrès de chaque époque, et même de chaque génération, résulteraient nécéssairement toujours de l'état immédiatement antérieur: en sorte que les hommes de génie, auxquels ils sont, d'ordinaire, trop exclusivement attribués, ne se présentaient essentiellement que comme les organes propres d'un mouvement prédeterminé, qui, à leur défaut, se fat ouvert d'autres issues» $\left.{ }^{48}\right)$. Será tão só nesse sentido que os nossos positivistas entenderão a celebração da memória dos

(*) Veja-se Fernando Catroga, «Os inícios do positivismo...», ob. cit., pp. 330-352.

(i) Idem, pp. 357-362.

(48) Augusto Comte, Cours de Philosophie Positive, reimpressão anastática da edição original, vol. IV, Paris, Antropos, 1969, p. 298. 
grandes vultos: para eles, "o homem, ou melhor, a Humanidade, surgia como um indivíduo sucessivamente melhorado através da acção dos povos e nos actos dos indivíduos» ( ${ }^{(8)}$ ). A evocação do exemplo da sua acção será então considerada, na medida única em que esta tenha trazido elementos dinâmicos à evolução progressiva das sociedades. Todavia, tal como o entendera também a escola heterodoxa de Littré, esse acto não será materializado de uma forma meramente cultural, religiosa, mas apenas enquanto possa servir como modelo para a constituição de um sentimento colectivo actuante.

A criação de um ambiente emocional à volta da celebração dos grandes do passado, efectuada no decurso das comemorações centenárias, irá, assim, ajustar-se optimamente às intenções ideológicas e políticas dos republicanos, permitindo, num mesmo tempo, apoiar a vulgarização de ideias e atitudes consideradas exemplares, e pôr em causa o poder político monárquico, ao destacar a oposição entre um passado considerado brilhante e um presente de desadência e humilhação nacional.

Teófilo Braga irá tornar-se o principal mentor desta atitude, falando, já em 1879, das comemorações camoneanas a efectuar em $80\left({ }^{58}\right)$. Em 1884, no Systema de Sociologia, apresentará então, de uma forma mais precisa e elaborada, as suas ideias a esse respeito. Reconhecendo aí afastar-se de Augusto Comte, "quanto às suas formas religiosas», que justifica pela "orientação sentimental do século XVIII" que este teria recebido e que o teriam conduzido a elaborar fantasias por pretender "ir mais longe do que o permite a marcha espontânea dos factos», Teófilo aceita, no entanto, que "nas sociedades modernas alguma coisa se passa, que tendendo a satisfazer as necessidades de sentimento, vai ao mesmo tempo substituindo as religiōes" ( $\left.{ }^{51}\right)$.

Seguindo Comte, Teófilo apontará então a sintese activa, forma de acordo mútuo entre os indivíduos para a satisfação das suas necessidades materiais, como sendo "realizada espontaneamente nas Exposições»; a síntese afectiva, como modalidade de aproximação simpática e altruista dos homens, motivada por preceitos de ordem ética e manifestando-se "pelos Centenários dos grandes homens e dos grandes sucessos»; fi-

pp. 357-358.

$\left.{ }^{(0)}\right)$ Teófilo Braga, «O Centenário de Camões de 1880», in $O$ Positivismo, n..$^{\circ}$, ano II, Outubro-Novembro, 1879, pp. 1-9.

${ }^{\left({ }^{11}\right)}$ Teófilo Braga, Systema de Sociologia, 2." ed., Porto, Livraria Chardron, 1908, p. 16. 
nalmente, a sintese especulativa, estádio superior de organização da sociedade alcançado pelo desenvolvimento das capacidades mentais e da actividade especulativa, «efectua-se por meio dos Congressos, em que a pátria se alarga na humanidade» $\left.{ }^{52}\right)$. Representará, assim, as comemorações centenárias, como momentos de mobilização moral dos indivíduos e das comunidades, funcionando também como sucedâneos das antigas manifestações religiosas e tendo em vista o desenvolvimento de um ideal de vivência em sociedade.

Conjuntamente, aproximará essas homenagens de formas de expressão de um "nacionalismo" capaz de mobilizar as maiorias: «Depois dos Congressos e das Exposições, que são por assim dizer os concílios e os jubileus da inteligência e da actividade humana, os Centenários dos grandes homens são as festas das consagrações nacionais. Cada povo escolhe o seu génio, que é a síntese do seu carácter nacional; aquele que melhor exprimiu essas tendências, ou que mais serviu essa individualidade étnica; o vulto de Cervantes simbolizará em todos os tempos a Espanha, como Voltaire representa em todas as suas manifestações o génio francês; Dante, Petrarca e Miguel Angelo para a Itália, Shakespeare e Newton para a Inglaterra, Lutero e Göethe para a Alemanha, Espinosa para a Holanda, são laços por onde estes povos, mantendo o seu individualismo nacional, se prendem ao grande conflito da história com esforços colectivos que conduzirão para a noção da Humanidade que se afirma" $\left({ }^{53}\right)$. Efectuar-se-á deste modo, e nesses momentos, uma adopção dos valores basilares da pátria por parte de todos quantos se identificam com aquele que consideram o seu símbolo, apontando-se os que, do lado do poder, combatem o evidente aproveitamento político das solenidades e são tomados por fautores de uma situação de decadência como elementos antinacionais e retrógrados que importa afastar.

Mas não será somente Teófilo a conzeber desta forma e nesta perspectiva doutrinária as celebrações centenárias. Já durante as comemorações pombalinas. Carlos Lobo d'Ávila, então jovem estudante positivista de Coimbra, poderia dizer num caloroso discurso pronunoiado no Teatro Académizo acerca do papel histórico das grandes individualidades: "Houve tempo em que se supunha que estava dependente da acção humana marcar o curso que deveria seguir a humanidade no seu

${ }_{\left({ }^{52}\right)}$ Idem, pp. 17 e 308-309.

(s) Teófilo Braga, Os Centenarios como suntese affectiva nns sociedades modernas, Porto, Typ. de A. J. da Silva Teixeira, 1884, pp. 4-5. 


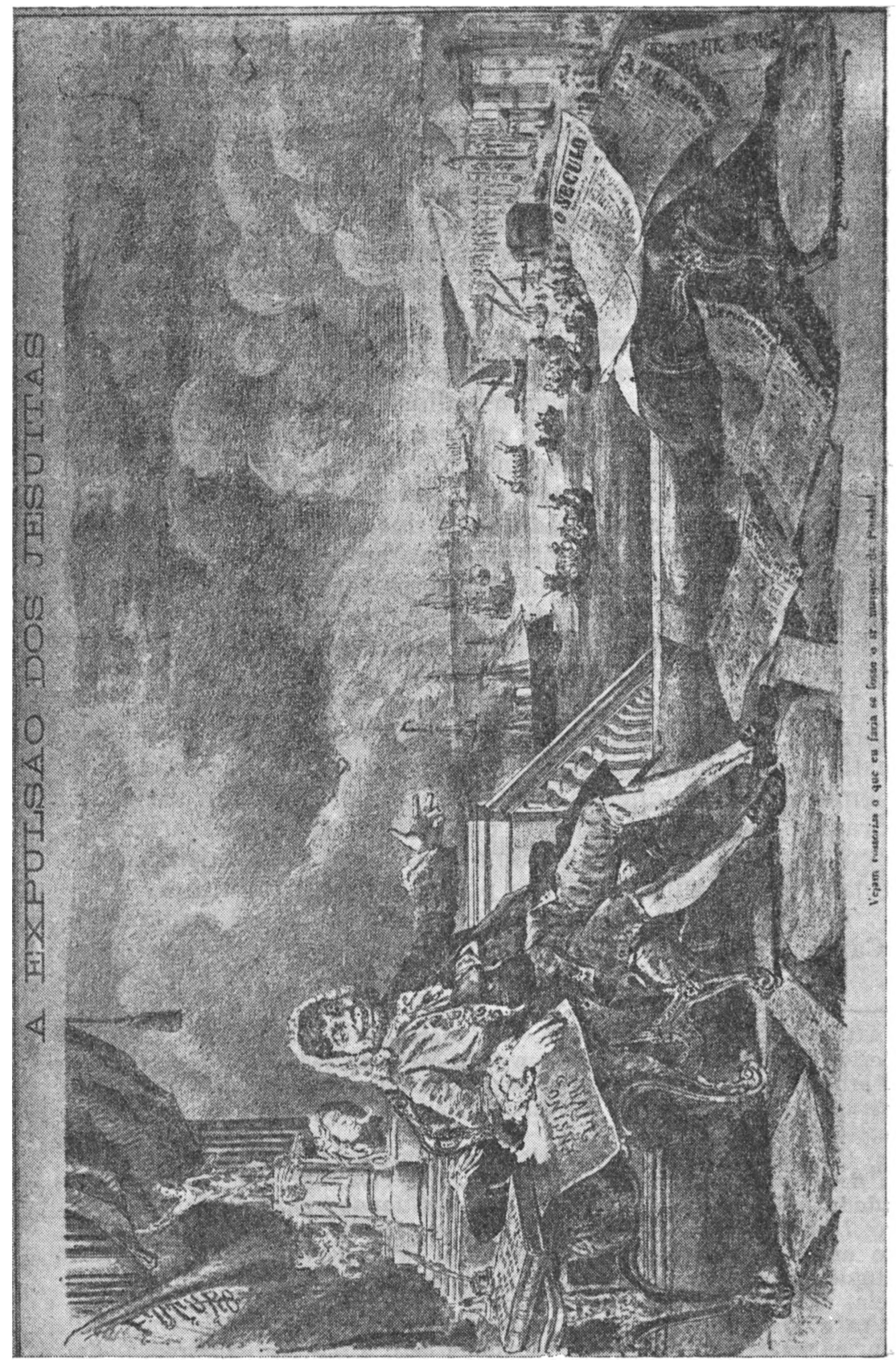

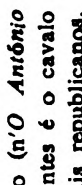

운 응

도용

语

음 웛 융

영잉

ฮ뭉

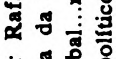

台芯苔

용

๑

¿

$>$ 品高

近음

숭ㅎㅇ

$\therefore$ 웅

올 잉

氙嵒嵒

웅



总吉

出

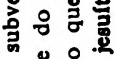

เ

巻

홍

हू

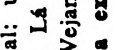

है

웜

氖 哥

हू

$\Sigma$ व

○二 。ํํㅇ

ㅇํㅇ

芺芯

ฉ

ㄴ.

ก 
caminhar através dos séculos.... Hoje sabe-se que a evolução da humanidade tem leis fatais e iniludíveis, que baldados serão todos os esforços humanos que pretendem opor-se à sua realização, e que os homens são apenas instrumentos mais ou menos conscientes, que põem em prática essas leis fatais. Mas o que não é menos certo, senhores, é que a acção individual não pode banir-se completamente da história, e o homem, se não pode impedir que afinal dêem o seu resultado prático as leis supremas da evolução progressiva da humanidade, pode, sim, fazer retardar ou acelerar a realização positiva dessas leis» ( $\left.{ }^{54}\right)$. Ao que Manuel Emídio Garcia, o velho pioneiro do positivismo lusíada, poderia acrescentar que, quando se comemoram os grandes homens, "é sempre em honra e para glória da humanidade, para marcar estádios nesse caminhar incessante da civilização universal, de que a humanidade é o infatigável, omnipotente e sábio criador, e não para impôr, em nome de um passado irrestaurável, às novas gerações, a adoração dos seus fetiches, a idolatria dos seus deuses, o culto dos seus, mas para lhes apontar o exemplo dos seus beneméritos" ${ }^{(8)}$ ). Davam-se assim os passos necessários para tornar efectiva uma certa «dessacralização» dos centenários e permitir, desse modo, a sua disposição ao serviço de um ideal de formação cívica e de combate político.

Para positivistas e republicanos, o sentido específico da celebração do centenário da morte de Pombal vai, todavia, revestir-se de um significado diferente daquele atribuído às comemorações camoneanas de 1880 . Outra coisa não seria de esperar: a figura do Marquês, polémica e ainda perturbante, não conseguiria, de forma alguma, suscitar o unanimismo quase total que a figura do nosso poeta nacional impusera.

Teófilo teria a percepção dessa diferença: "O centenário de Camões foi um levantamento da nação para a apoteose

(4) Carlos Lobo d'Âvila, «O Marquez de Pombal», discurso proferido no Teatro Académico em 6 de Maio de 1882, in $O$ Centenario do Marquez de Pombal, jornal commemorativo publicado pela comissão de estudantes de Coimbra, n. $^{\circ}$ único, Coimbra, Imprensa da Universidade, 1882 , p. 7.

( $\left.{ }^{85}\right)$ Manuel Emídio Garcia, «Marquez de Pombal», in O Marquez de Pombal. Obra commemorativa do centenario da sua morte, mandada publicar pelo Club de Regatas Guanabarense do Rio de Janeiro, Lisboa, Imprensa Nacional, 1885, p. 131. t a refundição de um texto anterior, que parece constituir o primeiro que o positivismo português produziu acerca da figura do Marquês: Manuel Emídio Garcia, O Marquez de Pombal. Lance de olhos sobre a sua sciencia politica e systema de administração; ideas liberais que o dominaram; plano $e$ primeiras tentativas democraticas, Coimbra, Imprensa da Universidade, 1869. 
da individualidade que a simboliza. No Marquês de Pombal vemos a forte actuação exercida no seu meio social, com a expulsão dos jesuítas, a secularização da instrução pública, a reacção contra a absorção comercial da Inglaterra, a abolição da escravatura, o desenvolvimento das indústrias... $\left({ }^{58}\right)$. Nesse mesmo sentido, $A$ Folha do Povo, jornal republicano de Lisboa, escreverá no dia da celebração: «Se o centenário de Camões nos indicou uma época de revivescência nacional, o centenário do Marquês de Pombal dá-nos a orientação do povo português, porque, rompendo as peias que o ligavam ao passado, ministra-lhe a luz que o deve guiar para conseguir libertar-se da indecisão em que tem jazido. $\mathrm{O}$ centenário de $\mathrm{Ca}$ mões fez-lhe lembrar que tinha sido grande, e, fazendo reviver o entusiasmo pelas glórias passadas, deu-lhe a força para se levantar do abatimento em que o prostrou a sua indiferença. O centenário do Marquês de Pombal abre uma brecha entre os que representam o passado e os que olham para o futuro.... O centenário do Marquês de Pombal vem delimitar perfeitamente os campos em que, de um lado, está a nobreza, o clero, e os que sobre estes elementos assentam o seu poder, e, do outro lado, os que trabalham, sofrem e desejam ver cumpridas as leis e respeitada a dignidade nacional, que não deve estar à mercê das garras ambiciosas do estrangeiro" $\left({ }^{57}\right)$.

Mas há quem, neste género de considerações, seja ainda mais veemente, proclamando em tom altissonante: «Camões é uma tradição, a cuja sombra é grato viver indolentemente recostado; Pombal é um raio, que deslumbra, fere, mata, incendeia, mas esclarece; Camões é um cântico, Pombal é uma luta; cântico de glória pelo que fomos, de agonia pelo que íamos ser; luta forte, enérgica, máscula, vivificante, contra todos os elementos que haviam entorpecido as forças vitais do país e pretendiam governá-lo, sem se lembrarem de que o aniquilavam» $\left({ }^{58}\right)$.

No domínio da justificação teorética da importância de Pombal, e defendendo que se homenageie a sua figura e a sua obra, escreve-se então em $A$ Euolução, de Coimbra: «Foi ele o primeiro que, em Portugal, pressentiu a transformação do estado teológico feudal em estado científico industrial, a qual

1882, (so $_{\text {(s) }}$ 1. Francisco Maria Gomes do Rego Feio, Discurso pronunciado no grande comicio anti-jesuítico por ocasião do centenario do Marquez de Pombal em Coimbra, Coimbra, 1882, p. 7. 
tão vigorosamente se vai operando nos nossos dias» $\left({ }^{50}\right)$, o que seria, decerto, um exagerado mas conveniente enquadramento da acção da figura do Marquês. Nesse mesmo número de $A$ Evolução - ainda que mais na perspectiva do combate político - escreverá Teófilo: «Foi assim o Marquês de Pombal, desobstruiu o caminho para uma mais fácil eliminação da realeza, embora essa obra saísse contrária ao seu intuito. A sua acção, a sua própria individualidade, anulando ou subalternizando o poder monárquico hereditário diante da superioridade do poder ministrial, revelam-nos que se aproxima a época em que a soberania, derivada da nação, será delegada no mais competente» $\left({ }^{60}\right)$.

Porém, alguns dos traços definidores da acção do ministro de D. José ficavam na sombra, sendo eles justamente os que não se podiam, de forma alguma, conformar com o democratismo social e o liberalismo político republicanos. 0 reforço do aparelho de Estado e dos privilégios reais, o desenvolvimento da censura literária e intelectual $\left({ }^{61}\right)$, a chamada política das companhias (ligada à restrição da liberdade de comércio), a dura repressão dos descontentes, constituiriam as. pectos da acção do Marquês que importava silenciar e que os adversários do centenário não deixariam nunca de invocar.

Neste caso - como aconteserá também, em 1892, com a homenagem a Joaquim António de Aguiar - tratar-se-á, sobretudo "de enaltecer a acção de estadistas anticlericais, acusar a conivência do constitucionalismo com a crescente influência das ordens religiosas e, com isso, sensibilizar as massas populares para um problema crucial da estratégia republicana: a luta contra a dominância ideológica do clero ultramontano» ( ${ }^{62}$ ). Para os republicanos, seriam o clero e a monarquia a pagar a factura dos festejos pombalinos de 1882 .

$\left({ }^{50}\right)$ Manuel Emídio Garcia, «O Marquez de Pombal», in $A$ Evoluçáo, semanario ièusiicano Loimbra, número especial comemorativo do centenário, 8 de Maio de 1882 .

$\left({ }^{\circ 0}\right)$ Teófilo Braga, «Missão historica do Marquez de Pombal», in $A$ Evoluçã̃o, 8 de Maio de 1882, p. 4.

$\left({ }^{61}\right)$ A Real Mesa Censória proibiria as obras que, de uma qualquer forma, pudessem pôr em causa o poder absoluto dos reis. O Catálogo de livros defesos, de 1768, e o Edital de 24 de Setembro de 1770, banirão edições de Maquiavel (os Discorsi e não Il Principe) Thomas More, Jean Bodin, Hobbes (especialmente o Leviathan), Roberto Bellarmino, Francisco Suárez, Espinosa, Erasmo, Helvetius, Rousseau, Condillac, Bailly, Voltaire (toda a sua obra), Diderot, D'Alembert, Condorcet, Shaftesbury, etc. ob. cit., p. 314 .

${ }^{\left({ }^{(2)}\right)}$ Fernando Catroga, «A importância do positivismo...», 


\section{Monárquicos e maçãos}

O tricentenário da morte de Camões tinha-se transformado num imenso movimento democrático e patriótico, que o alheamento oficial tinha convertido numa grande vitória dos republicanos. Revivendo-se então um período de "grandeza nacional", tinha-se responsabilizado a monarquia constitucional pelo estado de decadência do país, enquanto os repur blicanos se apresentavam como os redentores da nação. Em Lisboa, no próprio dia do cortejo camoneano, o retrato do rei era estrondosamente pateado no Coliseu. A aspiração republicana de, dois anos volvidos, reatar as gloriosas jornadas de 80 vai agora, todavia, confrontar-se com uma situação bastante diferente.

Os partidos monárquicos tinham aprendido a lição. Procurando evitar que se repetisse o desaire, que tão graves consequências tivera para o crédito e a estabilidade das instituições e do rotativismo, progressistas e regeneradores irão, à sua maneira, tentar conferir às comemorações pombalinas o carácter de "unânime" confraternização dos diversos elementos da nação, buscando assim diluir o carácter combativo e de contestacão ao regime que republicanos e socialistas pretendiam atribuir ao acontecimento.

Teófilo verá a realidade dos factos sob uma outra perspectiva: "O que o governo progressista fez em 1880 , foi repetido em 1882 pelo governo regenerador, com aquela deplorável fatalidade de quem obedece inconscientemente a uma força latente de dissolução, e, portanto, com uma certa irresponsabilidade. Não devemos querer-lhe mal por isso; a evolução segue o seu caminho, a despeito da irracionalidade do poder sem plano, que julga que o governo é o aparato da força, a ordem, a repressão, e o bem-estar geral o conservantismo" ( $\left.{ }^{83}\right)$. Todavia, apesar desta afirmação, o poder regenerador - que tinha substituído o ministério "progressista" de Anselmo Braamcamp - não se iria opôr nem alhear inteiramente dos factos, não só porque se tivesse apercebido do perigo dessa atitude, mas ainda porque tal atitude o poderia prejudicar no seu combate político.

O que é um facto é que o partido de Fontes, como partido no poder, tinha muito mais a perder com a celebração de mais um centenário "revolucionário" do que os progressistas. Irá, por isso, e principalmente, procurar evitar os «excessos». Os próprios progressistas reconhecerão a relativa mo-

("s) Teófilo Braga, Os Centenarios..., ob. cit., p. 222. 
deração da atitude regeneradora: «Exultamos com este nobre movimento dos espíritos. Exultamos e tanto mais nos alegramos quanto o vemos profundamente acentuado e largamente generalizado, por forma que o tacanho governo regenerador, apesar da sua má vontade, e não obstante a sua triste subserviência em relação aos jesuítas, não se atreve a combatê-lo de frente, nem a opor-se claramente aos intuitos nacionais» ( $\left.{ }^{64}\right)$.

O Partido Regenerador vai, assim, participar nas comemorações, não dando porém um passo para as incentivar, impedindo certos actos considerados perigosos (como a conferência que Manuel Emídio Garcia deveria ter feito no Porto e uma outra que Teófilo Braga proferiria em Lisboa) e acabando até por ordenar a repressão violenta de uma marcha com archotes, com a qual os republicanos encerravam as cerimónias de Lisboa. Nesta perspectiva, irá mesmo atacar o empenhamento posto nos acontecimentos pelos progressistas, como o demonstra o que se escreveu na regeneradora Correspondência de Coimbra: «Começa a ser explorada pela imprensa progressista a festa nacional.... O melhor é que os republicanos, ameaçados de sova pelo estadulho do Progresso $\left({ }^{85}\right)$, quando foi do tricentenário camoneano, andam agora de braço dado no desvirtuamento da significação patriótica do centenário do Marquês de Pombal» $\left({ }^{\circ 8}\right)$. Escamoteando o sentido combativo que a oposição pretendia conferir às homenagens em memória do Marquês, Pinheiro Chagas colocaria este no panteão dos fautores de um mítico "progresso" de toda a humanidade, cristalizador da acção criativa das sociedades, mas, por isso mesmo, pacifico e unanimista, como convinha ao poder regenerador ${ }^{\left({ }^{\circ}\right)}$.

Pelo seu lado, os progressistas irão colocar a sua participação nas comemorações sob uma perspectiva de oposição ao governo fontista, e, claro, de promoção própria. De uma forma particularmente activa, participam então em comissões e grupos de trabalho, incorporam-se em comícios e desfiles públicos, enquanto a sua imprensa se enche de secções

\footnotetext{
(a) O Tribuno Popular, Coimbra, n.॰ 2738, ano XXVI, 6 de Maio de 1882, p. 1.

${ }^{\left({ }^{05}\right)}$ Trata-se de uma referência a $O$ Progresso, de Lisboa, jornal do Partido Progressista.

$\left(^{\infty}\right)$ Correspondência de Coimbra, Coimbra, n..$^{\circ} 28$, ano XI, 11 de Abril de 1882, p. 1. Note-se que esta é uma das pouquíssimas referências que este bissemanário faz às comemoraçōes.

("7) Veja-se Pinheiro Chagas, «Os Centenarios», in O Campeão das Provincias, Aveiro, n. ${ }^{\circ}$ 3057, ano XXIX, 14 de Janeiro de 1882, p. 3.
} 
pombalinas e publica vistosos números comemorativos ( $\left.{ }^{(8)}\right)$, ao mesmo tempo que condena a inépcia dos regeneradores.

No seu conjunto, porém, os dois partidos monárquicos e esta é uma componente fundamental da sua atitude face ao centenário pombalino - são concordantes em sublinhar o carácter antijesuítico da acção do Marquês e em condenar, com veemência, a forma cerrada e clamorosa segundo a qual os ultramontanos atacavam o centenário e a figura de Sebastião José. Uma parte considerável dos artigos surgidos então a lume na imprensa laica, monárquica ou não, empenha-se pois, especialmente, na refutação das opiniōes expressas na imprensa clerical.

Este facto apresenta-se-nos como indissociável da posição fundamentalmente antiliberal e visceralmente antimaçónica da Igreja portuguesa. Aqueles que dela se afastam nestes domínios, servir-se-ão essencialmente do sentido antijesuítico da acção de Pombal para contrariar a crescente intromissão daquela congregação, e do clero católico em geral, na vida política, cultural e social do país.

Pelo que lhe tocava, a imprensa e as organizações católicas reagiam de uma forma assaz primária e até violenta, utilizando os eventos ligados ao centenário para sucessivas profissões de fé antiliberal. Aqui, os termos e os argumentos utilizados pela Palavra e $O$ Progresso Católico, ligados aos católicos «liberais», em nada diferem daqueles de que se servem $A$ Ordem ou $A$ Nação, declaradamente legitimistas. Por essa altura, escreve um certo Ribeiro a Joaquim Martins de Carvalho, numa insultuosa carta que $O$ Conimbricense publicará na íntegra: $\propto O$ tal centenário é pior que uma pouca vergonha maçónica, pior do que um crime; é uma tremenda asneira liberal» $\left({ }^{68}\right)$. Tais palavras seriam de pouca importância se nos não dessem o tom de uma campanha que era geral.

O agastamento católico será acrescido pelo apoio dado pela maçonaria, sua adversária natural, às comemorações pombalinas. Na realidade, esse suporte seria porém muito limitado.

De um ponto de vista organizativo geral - que não local ou individual - a maçonaria agiu efectivamente de uma forma apagada, ao longo de grande parte do processo. A tal facto não será com toda a certeza estranha a circunstância de se

${ }^{(8)}$ Como é o caso de, por exemplo, O Progressista, de Coimbra, cuja colecção de 1882 compulsámos e onde se demonstra invulgar empenhamento na promoção do centenário.

$\left(^{\circ}\right) O$ Conimbricense, Coimbra, n..$^{\circ} 3623$, ano XXXV, 2 de Maio de 1882, p. 2. 
encontrar ainda, numa boa parte, ligada ao regime monárquico: em 1882, falava-se até da figura de Fernando de Saxe-Coburgo, o viúvo de D. Maria II, para substituir o conde de Paraty no grão-mestrado do Grande Oriente $\left({ }^{70}\right)$. E, para além de ter sido a imprensa maçónica uma das primeiras a falar do centenário e aquela de onde partiu a ideia do levantamento de uma estátua ao Marquês, verificamos que, pelo menos ao nível central, pouca importância atribui depois ao acontecimento, o que está de acordo com as constantes queixas nesse sentido expressas por diversas publicações republicanas (como é o caso de $A$ Folha do Povo).

Assim, o Boletim Official do Grande Oriente Lusitano Unido faz, durante todo o ano de 1882, duas brevíssimas referências ao centenário, sublinhando essencialmente o carácter anticlerical (e especialmente antijesuítico) que entende que este deve tomar. Pelo seu lado, $O$ Malhete, ligado à cisão de José Dias Ferreira e da Grande Loja Simbólica de Portugal, apesar de atribuir um maior relevo ao evento, parece nele não pretender (ou não poder) assumir um papel especialmente activo $\left(^{71}\right)$. Uma e outra das publicações são, afinal, bem mais lacónicas a este respeito do que a generalidade da imprensa clerical e partidária.

Tal não significa, porém, que se negue a importante actividade desenvolvida, por alguns maçãos e deteminadas lojas, na preparação e na condução das comemorações. Em Coimbra, por exemplo, a Associação Liberal, ligada à maçonaria, teve influente papel nos acontecimentos, tal qual o tiveram também reconhecidos «irmãos», como Joaquim Martins de Carvalho, Abílio Roque e Manuel Emídio Garcia, das lojas Preseverança e Federação.

\section{A atitude socialista}

Entretanto, confrontados com a sua fraqueza organizativa, o limitado apoio social que tinham e as suas próprias querelas internas, os socialistas não se encontravam em condições

( $\left.{ }^{10}\right)$ Veja-se $A$ Folha do Povo, Lisboa, n. ${ }^{\circ} 466,4 .^{\circ}$ ano, 8 de Fevereiro de 1882, p. 3.

(i) Veja-se Boletim Official do Grande Oriente Lusitano Unido. Supremo Conselho da Maçonaria Portugueza, Lisboa, $3 .^{a}$ série, n. ${ }^{\circ}$ 3 , $13 .^{\circ}$ ano, Junho de 1881 ; n. $.^{\circ} 10-11,13 .^{\circ}$ ano, Janeiro-Fevereiro de

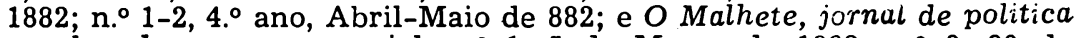
geral $e$ de progresso social, n. ${ }^{\circ} 1,5$ de Março de $1832 ; n .0^{\circ} 9,30$ de Abril de 1882; n. ${ }^{\circ} 10,7$ de Maio de 1882. 
de aproveitarem devidamente - combatendo-o ou apoiando-o, tendo num ou noutro dos casos as suas próprias posições - o «acontecimento político" relevante da vida portuguesa da época que foi o centenário.

A atitude geral do Partido, a tal respeito, foi afinal aque. la que a tendência dominante impunha, num prozesso de seguidismo político em relação aos republicanos, somente inteligível dada a ausência de um movimento operário socialmente autónomo e politicamente activo. A posição de um Carrilho Videira, que entretanto fora expulso da secção portuguesa da A. I.T., exprime uma das poucas vozes que tentava opor-se à corrente dos acontecimentos, escrevendo, em referência à campanha pombalina, que «enquanto o Partido Republisano atordoa as turbas com frases estafadas e lugares-comuns, vão aparecendo e surgindo no país elementos poderosos", capazes de suscitar a mudança ${ }^{72}$ ).

Como referimos atrás, a influência republicana e positivista absorvia os próprios socialistas, tornando-se até possível entrever na sua linguagem elementos que se prendem ao simbolismo maçónico. Assim, escreve $O$ Protesto Operário acerca das comemorações centenárias e do papel dos grandes vultos: «Se prosurarmos a verdadeira característica da civilização dos nossos dias, iremos encontrá-la nestas manifestações grandiosas de admiração e de civismo, de inteligência e de desprendimento. Não é o egoísmo nacional que se levanta proclamando heróis, é o respeito universal, a justiça colectiva, que se ergue generosa num rasgo espontâneo e maravilhoso, aclamando uníssona esses vultos agigantados, despojos humanizados dos velhos deuses tenebrosos, que puseram toda a sua vida ao serviço de uma ideia santa, toda a sua compreen. são ao dispôr de uma causa justa, toda a sua abnegação ao acumular de materiais valiosos, de ciência e de heroísmo, para a grande obra da civilização contemporânea. Não são deuses locais; são heróis universais. $O$ vento do pensamento espalhou-lhes as sementes pelo Universo, e o novo mundo encheu-se de frutos, de flores e de sóis, inundando-se de luz, iriçando-se de galas, como a natureza no período efervescente da seiva nova e fertilizadora.... Os centenários são a forma de expansão da compreensão colectiva, as válvulas de segurança da admiração ilustrada, o testemunho glorioso da gran-

( $\left.{ }^{12}\right)$ Referido por Carlos da Fonseca, ob. cit., II -Os primerros congressos operários, Lisboa, Europa-América, 1981, p. 131. 
de missão regeneradora, da concentração humana e fraterna do século XIX" $\left({ }^{73}\right)$.

Aludindo já, de uma forma concreta, à homenagem a Pombal, a secção Sul da Associação dos Trabalhadores da Região Portuguesa, ligada ao Partido Socialista, afirmará, num parecer acerca das comemorações, que lhe é difícil «a apreciação rigorosa do vulto estranho, mesclado de cintilações de luz e de estilhaços de treva, de Sebastião José de Carvalho e Melo», mas "seria suficiente a guerra movida pelos clericais ao centenário pombalino para que se justificasse a nossa adesão, a adesão dos inimigos da reacção, a grande comemoração iniciada com entusiasmo pela classe académica; seria bastante a alta expressão deste sentimento novo de justiça colectiva, traduzido pelos Centenários, para que se compreendesse o nosso apoio aquela comemoração justiceira» $\left({ }^{74}\right)$. O Protesto Operário poderia acrescentar ainda que "entre o aliar-se às negras legiões do jesuítismo que guerreiam o centenário e o confundir-se na turba multa dos indiferentes e dos cobardes, o proletariado português escolheu este caminho: o afirmar uma vez mais a sua honestidade e a dedicação pelas suas crenças, associando-se a uma manifestação anticatólica e antirreaccionária» $\left({ }^{75}\right)$.

Desta maneira, à sombra da bandeira republicana - a dos principais promotores do centenário - os socialistas tomaram a posição possível, nas fileiras de um exército que, de momento, combatia inimigos comuns: o clericalismo e a monarquia.

Pugnando, tal como os republicanos, pela laicização da sociedade e do Estado, os socialistas, para além das questões de natureza ideológica que naturalmente os separavam de Roma, iriam retorquir à intolerância do papado e do clero português. Para compreendermos esta sua atitude, basta-nos tomar em conta a carta encíclica Quod Apostolici Muneris, publicada em 28 de Dezembro de 1878 por Leão XIII: «E fácil compreender, Veneráveis Irmãos, que falamos daquela seita de homens, os quais, sob diversos e quase bárbaros nomes como socialistas, comunistas ou nihilistas, espalhados por todo o mundo e estreitamente coligados entre si por uma iníaua federacão, já não buscam defesa nas trevas das suas ocultas reuniões, mas, saindo à pública luz, confiantes e de cara des-

( $\left.{ }^{73}\right)$ Luís de Figueiredo, «Os centenarios», in O Protesto Operário, órgão do Partido Operário Socialista, Lisboa-Porto, n. ${ }^{\circ} 7,1^{\circ}$ ano, 16 de Abril de 1882.

p. 2 .

(") O Protesto Operário..., n.० 8, 1.० ano, 23 de Abril de 1882,

$\left(^{75}\right)$ Idem, n. $.^{\circ} 10,1 .^{\circ}$ ano, 7 de Maio de 1882, p. 2. 
coberta, empenham-se em levar a cabo o plano, que conceberam, de alterar os fundamentos de toda a sociedade civil. Estes são certamente aqueles que, segundo atestam as divinas páginas, ofendem a carne, desprezam a autoridade e blasfemam da majestade.... Estas monstruosas opiniões, são aquelas que publicitam nas suas reuniões, aconselham nos seus folhetos e espalham pelo público numa nuvem de diários, e por causa das quais a venerável majestade e o império dos reis chegaram a ser objecto de tão grande ódio por parte do povo sedicioso, sacrílegos traidores não puderam ser refreados e, por mais de uma vez e em curto espaço de tempo, voltaram as suas armas com ímpio atrevimento contra os mesmos príncipes» $\left({ }^{78}\right)$.

O papel dos socialistas nas comemorações seria pois, apesar da sua combatividade, muito limitado: para além de algumas declarações públicas e do apoio da sua imprensa, lá seguiu uma reduzida mas buliçosa porção nos desfiles efectuados. Escreverá Azedo Gneco: "Veio o centenário do Marquês de Pombal e de novo comparecemos com o nosso pendão. A polícia interveio de novo e tirou-nos a bandeira, no meio de gerais clamores; mas como nos tirou só a bandeira e nos deixou a haste, lá fomos no cortejo de vara alçada, com um ramo de perpétuas preso de uma fita vermelha. $E$ as saudações partiram de todos os lados à vara do nosso pendão!" $\left({ }^{77}\right)$. Os «banhos de multidão» do Partido assumiam ainda um cunho essencialmente emblemático.

\section{$O$ anticlericalismo}

Verificámos já o carácter anticlerical que, em Portugal, tomavam as propostas e a prática da generalidade dos partidos e das organizaçōes laicas. No decurso das comemorações pombalinas - tal como, um ano antes, aquando do lançamento de uma violenta campanha antijesuítica - esse dado tornou-se evidente e foi particularmente explicitado. A atitude da parte atingida seria consentânea com essa realidade.

O clero católico, legitimista ou «liberal», sentiu-se incomodado com os acontecimentos. E de tal forma que, ainda em 1906, o padre Silvano, redactor de A Ordem em 1882 e então envolvido em acesas polémicas em torno do centenário, se sentiu motivado para escrever mais uma violenta diatribe

(") Referido por Victor Manuel Arbeola, ob. cit., pp. 18-19.

(") «Carta de Azedo Gneco a José Veríssimo de Moura e Almeida», transcrita por César Nogueira, Notas para a historia do socialismo em Portugal (1871-1910), Lisboa, Portugália, 1964, p. 137. 
antipombalina $\left({ }^{78}\right)$. Vimos qual a fundamentação ideológica deste estado de espírito, especialmente derivado de uma incapacidade manifesta para entender as novas realidades do mundo liberal. Podemos, agora, traçar uma breve panorâmica do posicionamento católico e da argumentação dos seus opositores.

A reacção ultramontana, em conexão com o centenário, começou muito cedo, quando ele mais não era ainda do que uma vaga ideia, aqui e além aflorada. Em Coimbra, como exemplo, A Ordem inicia logo em Janeiro de 1882 a sua campanha, que ocupará largo espaço de todos os números que até Junho irão sair. Noticia então os acontecimentos na cidade, nos quais os seus redactores, um tal Mariz e o já referido Silvano, se viram constantemente envolvidos, na condição de solitária mas combativa oposição; publica virulentos artigos que vão procurar demolir a figura e a obra do Marquês; lança um abaixo-assinado que párocos e congregações vão fazer cîrcular pelos mais recônditos lugares; reproduz cartas (e até "poemas") que anatematizam a figura do ministro e, mais ain$\mathrm{da}$, a daqueles que se levantam como seus advogados.

A violência verbal é uma constante. Aí se escreve: «Para castigo dos centenaristas, eu não queria senão que fosse possível, só por uma semana, tornar a este mundo o Marquês de Pombal e D. José I.... Tenham a certeza, senhores liberais do centenário, que naqueles sete dias eram vocês todos rodados, esquartejados, queimados vivos ou, por muito favor, enforcados» $\left.{ }^{79}\right)$. Os números de 6 e de 10 de Maio aparecerão tarjados de negro e cobertos de esconjuradoras cruzes. No seu zelo demolidor aquela folha clerical acaba mesmo por elogiar o centenário camoneano: «Em 1880 era toda a nação que se empenhava nos festejos do cantor das glórias portuguesas; hoje são somente os livres pensadores, os positivistas e os chafariqueiros $\left({ }^{80}\right)$ que têm em mira exaltar os efeitos de Sebastião José de Carvalho e Melo" ${ }^{\left({ }^{81}\right.}$ ).

A Palavra, ligada ao sector católico «liberal», mostra-se mais ponderada e ciente do significado autêntico das comemorações: "Não se trata de prestar homenagem à memória de

$\left({ }^{78}\right)$ Veja-se Almeida Silvano, O Marquez de Pombal celebrado por um grupo de distintos escritores liberais, Lisboa, «O Bem Público», 1906.

(") Augusto de Pinho Leal, «O centenario do Marquez de Pombal», in A Ordem, Coimbra, n. ${ }^{\circ} 345$, IV ano. 22 de Maro de 1882 , p. 1.

${ }^{\left({ }^{80}\right)}$ Palavra que é simultaneamente sinónimo de mação, maçónico e de mixordeiro, taberneiro (Cf. Dicionário de Sinónimos, compilação da Tertúlia Edípica, Porto, s.d.).

(') $A$ Ordem, n. ${ }^{\circ} 359$, IV ano, 10 de Maio de 1882, p. 2. 
um homem - isso, para nós, está fora de qualquer dúvida trata-se simplesmente de fazer uma demonstração política, meramente política, e até certo ponto indecorosa» $\left.{ }^{82}\right)$. $\mathrm{O}$ que, convenhamos, era a verdade... olhada pela parte mais atingida.

Mas a actividade católica não se limitaria ao labor da imprensa. Justamente no dia 8 de Maio seria organizada uma grande peregrinação ao Sameiro, onde seria oficiada uma missa pelas vítimas do Marquês e feitas diversas pregações onde se estigmatizaria o centenário e os seus promotores. Falando da assembleia então presente, bradava uma folha ultramontana: «Além o Portugal louco, aqui o Portugal crente! Além a Revolução, aqui Deus!» $\left.{ }^{83}\right)$. O centenário pombalino teria ainda a sua revanche anos depois, em 1895, por alturas da celebração do centenário de Santo António, justamente efectuado aquando de uma nova e tempestuosa campanha laicizante e antijesuítica.

A atitude clerical não fará senão reforçar o movimento de combate às posições católicas. Júlio de Matos, apoiando-se no exemplo de Pombal, apontará o caminho que positivistas e republicanos entenderiam ser o mais correcto para pôr termo à dominação eclesiástica: "A história do Marquês de Pombal deve servir-nos de exemplo e de lição. Há em todas as questões de transformação social, como em todas as de transformação biológica, um factor de aue se não pode prescindir: é o tempo. $\mathbf{O}$ processo revolucionário, consequência metafísica das doutrinas e concepções políticas anteriores à constituição científica da sociologia, pretendendo suprimir aquele factor. há-de conduzir sempre, e fatalmente, ao insucesso. Simulará transformações, mas não as fará.... O Marquês de Pombal, em meados do século XVIII, expulsou para sempre de Portugal e seus domínios os iesuítas, por um decreto revolucionário; e, contudo, ao declinar do sézulo XIX, cento e vinte e três anos depois do decreto, os jesuítas vivem ainda ao nosso lado.... Assim é sempre: as instituições que se radicaram nos espíritos não se destroem de um momento para o outro, a golpes de pena ou de espada. O processo a aplicar nos nossos dias é outro: mais moroso, decerto, mas mais radical e mais seguro.... Os meios a empregar para chegar a esse fim são os próprios jesuítas que no-lo ensinam. Eles têm o púlpito, o confessionário e a escola; empreguemos nós armas iguais, que

\footnotetext{
(82) A Palavra, Porto, n. ${ }^{82914}$, ano X, 12 de Maio de 1882, p. 1.

(8) A Cruz e a Espada. Por Deus, Pátria e Rei, Braga, n. ${ }^{\circ} 15$, $1 .^{\circ}$ ano, 6 de Maio de 1882, p. 1.
} 
as temos: a imprensa, as conferências populares, a escola também. Proceder assim é seguir o caminho seguro. E este o processo evolutivo, único eficaz» $\left.{ }^{84}\right)$. Procura-se pois, desta forma, dar um sentido orientado ao anticlericalismo e ao antijesuítismo que, por alturas do centenário, constituem ainda, e sobretudo, sinónimos de liberalismo.

\section{AS COMEMORAÇŐES}

Torna-se difícil determinar a origem da iniciativa das comemorações. Francisco Reis Santos, na Historia do Regimen Republicano em Portugal, afirma ter sido a mocidade escolar quem primeiramente animou a realização do centenário ${ }^{\left({ }^{85}\right)}$. Brito Aranha é da mesma opinião, sublinhando que "a ideia da celebração do centenário teve origem numa reunião de estudantes das escolas superiores de Lisboa, que logo conseguiram a adesão das escolas de todo o país, incluindo a Universidade de Coimbra e a Academia do Porto; de muitos cidadãos de várias categorias e classes, incluindo a comercial e a industrial; do governo, das câmaras legislativas, da municipalidade de Lisboa, etc." $\left.{ }^{88}\right)$.

Todavia, uma primeira referência pública ao centenário surgira já em Junho de 1881, quando o Boletim Official do Grande Oriente Lusitano Unido lança a ideia de levantar um monumento à memória do Marquês $\left({ }^{87}\right)$. Ainda que esta informação pareça correcta, a maçonaria, como vimos, não deverá, pelo menos de uma forma global, ter-se empenhado muito na prossecução daquilo que incentivara. Tal é, aliás, a opinião de

(*) Júlio de Matos, «O Marquez de Pombal e a companhia de Jesus», in O Marquez de Pombal. Obra commemorativa do centenario da sua morte, mandada publicar pelo Clube de Regatas Guanabarense do Rio de Janeiro, ob. cit., pp. 206-208.

${ }^{\left({ }^{85}\right)}$ Francisco Reis Santos, ob. cit., p. 307.

(*) Brito Aranha, 0 centenario do Marquez de Pombal», in Dicionario Bibliographico Portuguez, de Inocêncio Francisco da Silva, tomo XIX, Lisboa, Imprensa Nacional, 1908, p. 45.

${ }^{87}$ ) Boletim Official do Grande Oriente Lusitano Unido, 3.a série, n. $3,13 .^{\circ}$ ano, Junho de 1881. Esse monumento, que deveria ocupar o espaço daquele que hoje vemos na Rotunda, teve aliás uma história atribulada: tendo então o Estado cedido o bronze necessário, tendo-se instituído uma comissão para promover uma subscrição pública, nada se fez e só o regime republicano voltaria à ideia. Depois de «primeiras pedras» em 1882, em 1917 e em 1926, somente em 34, e com diminuta solenidade, seria inaugurada (Cf. José-Augusto França, $A$ arte em Portugal no século XIX, vol. 2, Lisboa, Bertrand, 1967, pp. 317-321). 
A Folha do Povo, para quem «a maçonaria, que se levantara com rompantes de leão para celebrar o centenário de Sebastião José de Carvalho e Melo, que convocou as redacções de alguns jornais para se tratar dessa comemoração, que fez tanto espalhafato antijesuítico (só em palavras, entenda-se), não tem feito coisa alguma para coadjuvar a iniciativa da bizarra classe académica» $\left.{ }^{88}\right)$. O que não corresponde, evidentemente, à apreciação da imprensa ultramontana, que não se cansará de ver o dedo maçónico na sombra de tudo quanto se lhe oponha.

A proclamação da Comissão Académica, saída de uma reunião de estudantes que tivera lugar em Lisboa nos primeiros dias de Janeiro de 1882, constituirá, para todos os efeitos, o primeiro dosumento público que, de uma forma definida, apela à celebração do centenário e propõe medidas concretas para a sua efectivação ${ }^{89}$ ). A partir daí, diversas outras comissões se formam (em Coimbra, no Porto, etc.) e numerosas iniciativas começam, um pouco por todo o lado, a ganhar forma. $\mathbf{O}$ próprio governo, a câmara dos pares e a câmara dos deputados acabaram por tomar disposições no sentido de prover os meios para a construção do monumento e para a celebração das festividades, chegando, para esse efeito, a constituir-se uma "comissão nacional", presidida por Rodrigues Sampaio, e que apagado papel viria a ter.

$\mathrm{Na}$ verdade, seria aos estudantes, a instituiçōes ligadas à educação e a organizações políticas e cívicas que, de uma forma expressa, caberia a quase totalidade das iniciativas ou o apoio a estas.

Por todo o país se iniciou então a preparação do centenário, que, com efeito, viria a assumir as características de empenhamento cívico que os seus principais promotores tinham ambicionado.

No continente. no ultramar e até no Brasil, grande número de centros urbanos viu-se inundado, nos primerios meses do ano de 82 e com particular incidência no mês de Maio, por um sem número de sessões solenes, comícios. conferências, cortejos, espectáculos artísticos, livros, panfletos e iornais, os quais, partindo a um tempo do pretexto que era a elevacão (ou o deslustre) da memória do grande estadista, veiculavam, na prática, os desideratos políticos e culturais das diversas forças em presença. De Valença do Minho a Vila Real de Santo António, do Rio de Janeiro a Margão (na India),

(8) A Folha do Povo, Lisboa, n. ${ }^{\circ}$ 526, 4. ${ }^{\circ}$ ano, 20 de Abril de

(\$o) Aos estudantes e à colónia portugueza do Brasil, Lisboa, Associação Académica, 26 de Janeiro de 1882. 
passando por Braga, Viseu, Santarém, Marinha Grande, Tomar, Grândola, Sines, Faro ou Ponta Delgada, e, naturalmente, por Lisboa, Porto e Coimbra, ruas e salōes viram-se pejados de discursos apaixonados e vivas uníssonos que em muito ultrapassavam uma simples homenagem à figura e à obra de um homem.

Tornar-se-ia exaustivo um relato pormenorizado de todo esse movimento, que pode ser facilmente apreendido no compulsar da numerosa imprensa nacional e regional da época. Limitar-nos-emos, por tal motivo, a referir de uma forma sucinta os eventos de Coimbra e de Lisboa, afinal os locais em que as solenidades tiveram um maior significado.

Assim, em Coimbra, as comemorações colocaram academia e cidade numa actividade envolvente.

A ideia da celebração partira de um dos mais avançados elementos do corpo docente da Universidade, o positivista Correia Barata, o qual, em conselho da Faculdade de Filosofia de 15 de Novembro de 1881, "expondo os motivos porque a Universidade deveria tomar como suas as manifestações em honra da memória do Marquês de Pombal, apresentou uma proposta, que foi aprovada por unanimidade, resolvendo-se logo que fosse presente ao conselho de decanos, para determinar a forma aue se lhe deveria dar e o modo de se pôr em execução" $\left({ }^{80}\right)$. O conselho de decanos viria depois a aprovar a proposta, marcando uma reunião de todos os docentes, a qual, celebrada em 26 de Janeiro. aprovaria finalmente o programa das comemorações universitárias.

Entretanto, convocada pelo semanário republicano $A$ Evolucão ${ }^{{ }^{11}}$ ) e por um numeroso grupo de estudantes, a academia reuniria a 1 e 2 de Fevereiro para tratar do mesmo assunto. estimulada que estava pelo exemplo e o apoio dos seus colegas de Lisboa. marcando-se desde logo um sarau artístico no Clube Académico, a efertuar em Maio.

0 aspesto mais significativo dessas assembleias foi, no entanto, a entrada em cena dos redactores principais do iornal católico e legitimista $A$ Ordem, também eles estudantes, e que iriam desde logo constituir-se como solitária mas tenaz oposição ao centenário. 0 conflito manter-se-ia aceso até à extinção do eco dos acontecimentos de Maio, atingindo mesmo pontos violentos como a queima, junto à Porta Férrea, de numerosos exemplares de $A$ Ordem de 8 de Maio. 0 grupo de

\footnotetext{
$\left({ }^{\infty}\right)$ Annuario da Universidade de Coimbra. Ano lectivo de 1882 a 1883, Coimbra, Imprensa da Universidade, 1882, p. 4. 1882 , p. 1 .

(i) $A$ Evolução, Coimbra, n..$^{\circ} 11$, ano $1.0,6$ de Fevereiro de
} 
A Ordem representaria, afinal, o único bastião que em Coimbra procurava resistir à violenta campanha anticlerical e antijesuítica que varria a cidade.

A Universidade, pelo seu lado, celebraria Pombal de uma forma naturalmente moderada, como instituição maioritariamente conservadora e estreitamente ligada aos poderes públicos e à Igreja que era, sublinhando em essência a dívida moral que tinha para com o ministro seu reformador.

Desta maneira, no dia 8, depois de uma missa de requiem sufragando a memória do Marquês de Pombal e Conde de Oeiras, à qual assistiu o corpo docente, realizou-se na sala grande dos actos uma sessão solene onde, depois de uma brevíssima e protocolar alocução de abertura do Reitor, falaram os docentes Correia Barata e António Cândido. O primeiro proferiria um discurso que, pelo conteúdo e o tom extremamente moderado, surpreenderia até os homens de $A O r$ dem $\left({ }^{02}\right)$; António Cândido, eloquente e expressivo como era seu apanágio, proferiria uma empolgante peça oratória, de cariz essencialmente antijesuítico, que o faria ser o único docente aplaudido pela academia, a qual, reunida, o aguardava na Vial Latina $\left({ }^{(8)}\right.$ ).

Pelo seu lado, a Imprensa da Universidade assinalaria também os cem anos decorridos sobre a morte do seu fundador, decorando festivamente as suas instalações e descerrando, com a presença do seu administrador, Correia Barata. de todo o pessoal e de numerosos cidadãos, um magnífico quadro, impresso a ouro e cores, de Sebastião José.

A academia mostrar-se-ia, naturalmente, mais vibrante e polémica nas suas manifestações. No dia 6 , à noite, decorrera já no Teatro Académico um concorrido sarau literário e musical, com peças líricas e satíricas entremeadas de acalorados discursos e de vivas entusiásticos. No dia seguinte, realizar-se-ia no mesmo local uma assembleia de todos os estudantes, na qual se discutiram e formularam as principais carências científicas sentidas pelos estudantes, de entre as quais sobressaía a reivindicação da substituição da Faculdade de Teologia por uma Faculdade de Letras. Em seguida, as portas abriram-se à generalidade do núblico para se efectuar um comício antijesuítico. com o qual culminariam as comemorações acadé-

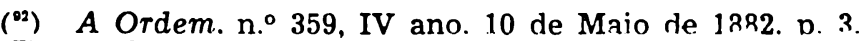

${ }^{(*)}$ O Conimbricense, n. ${ }^{\circ} 3625$. Ano XXXV. 10 de Maio de 1882. p. 2. O polémico discursn de Cândido seria um dos poucns que nunca seria publicado. nem mesmo narcialmente: ao que parere. o famoso tribuno improvisava os seus discursos, o que, a ser verdade. justificaria a lacuna. 
micas, nele se destacando o inflamado discurso de Trindade Coelho que, aludindo a atitudes de retaliação contra as solenidades pombalinas que tinham tido lugar em Mogadouro, no solar que ali haviam possuído os Távoras, terminaria calcando aos pés um exemplar de $A$ Ordem: "Não deixemos adormecer um instante sequer a consciência nacional, combatamos denodadamente pela nossa autonomia, lutemos pela existência, esmaguemos o jesuítismo nojento e asqueroso e caminhemos finalmente para a luz que é a simbolização maior e mais augusta da ideia de Progresso!» ( $\left.{ }^{94}\right)$.

Diversos organismos cívicos celebrariam também a memória de Pombal, como seria o caso da Associação Liberal. Esta Associação, fortemente influenciada por uma loja maçónica coimbrã, faria imprimir e distribuir profusamente um folheto, transcrevendo a lei pombalina de 3 de Setembro de 1759, que expulsou os jesuítas de Portugal, e o decreto de 28 de Maio de 1834, que fez sair do nosso país as restantes congregações religiosas. Aí se podia ler, na introducão que antecedia as referidas determinações: "Aquelas duas leis, que o poder legislativo não suspendeu ou revogou e aos governos pertencia fielmente executar, são letra morta; e os nossos homens de estado, os representantes do poder executivo, que deviam ser exemplares e enérgicos no cumprimento e observância das leis, sabiamente estabelecidas para garantia da liberdade, da ordem e do progresso, são os primeiros a esquecê-las, a sofismá-las até, em proveito da desordem e do retrocesso, em benefício dos reaccionários contra os liberais, para glória e engrandecimento da Companhia de Jesus, humilhação e decadência do nosso estado social, havendo partidos e imprensa, que se dizem e inculcam liberais, com coragem e cinismo bastantes para os sustentar e defender, ou pelo menos encobrir e desculpar» ${ }^{(85}$ ).

Para além da Associação, também o Centro Republicano da cidade e o Instituto de Coimbra $\left({ }^{98}\right)$ levaram a termo manifestações enquadradas no espírito do centenário.

Entretanto, em Lisboa, foi naturalmente muito elevado o número das cerimónias, da mais diversa índole, destinadas a recordar Pombal e os seus actos de governo. Outra coisa não de 1882, p. 3 .

(4) O Progressista, Coimbra, n. $.^{\circ} 1088,11 .^{\circ}$ ano, 11 de Maio

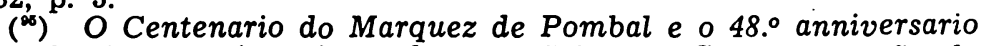
da entrada do Exercito Libertador em Coimbra. Commemoração da Associação Liberal, Coimbra, Casa Minerva, 1882, pp. 5-6.

${ }_{(\infty)}$ Veja-se O Instituto, Coimbra, vol. XXIX, n. 11-12 (especial), 1882, pp. 565-603. 


\section{O 1. Centendrio Pombalino}

seria de esperar: todas as forças em presença pretendiam aí, e à sua maneira, adaptar as manifestações em que participavam à forma própria que cada uma possuía de conceber as comemorações centenárias. Limitar-nos-emos, por essa razão, a referir momentos de maior importância e significado.

Inicialmente proposto por uma comissão académica, mas depois alargado a grupos pertencentes a associações profissionais, cívicas e culturais, a representantes dos sectores produtivos e a outros elementos, o cortejo cívico que no dia 8 de Maio atravessou a Baixa pombalina constituiu o ponto mais elevado das comemorações da capital, atestando, pela sua extensão e pela simpatia com que foi recebido pelas populações, um êxito para os seus promotores e para todos aqueles que pretendiam transformar as solenidades em actos de militância cívica.

O lançamento da primeira pedra do monumento que se pretendia erguer em memória do Marquês teve também um especial significado: em parte por ter partido de uma iniciativa maçónica, em parte também por contar com a presença do príncipe-herdeiro D. Carlos, o que levaria A Folha do Povo a escrever, não sem exagero, que «a maçonaria, conquanto seja uma sociedade secreta, é hoje instituição oficial da monarquia» $\left({ }^{(97}\right)$.

Finalmente, teve especial impacto a marcha aux flambeaux, com a qual os estudantes de Lisboa pretendiam honrar os seus camaradas de Coimbra e das outras academias do país, que tinham enviado representantes às cerimónias da capital. Talvez receoso da fogosidade reivindicativa, sempre possível em manifestações de jovens, ou da cobertura que a imprensa republicana estava a dar ao acto, o governo acabaria por reprimir aquele desfile, com guardas municipais e soldados carregando de sabre desembainhado sobre os numerosos populares que nele seguiam integrados. Atitude que seria, aliás, particularmente expressiva da "diversidade» dos modos de entender o primeiro centenário da morte do Marquês de Pombal.

\section{CONCLUSÃO}

De tudo quanto fica dito julgamos ser possível aprender o significado autêntico dos acontecimentos de 1882 .

Ele não representou, de forma alguma, a académica e asséptica celebração a que nos habituaram os «centenários»

(") A Folha do Povo, n. ${ }^{\circ} 543,4^{\circ}$ ano, 10 de Maio de 1882, p. 1. 
que, regularmente, vão hoje passando defronte dos nossos olhos. Foi sim, é lícito afirmá-lo, uma importante manifestação política, no decurso da qual as diversas correntes de opinião e os vários grupos sociais presentes na nossa sociedade fizeram confrontar forças e ideias.

Para os católicos, representaria o princípio do fim de um imobilismo de normas e de atitudes. Não no sentido duma abertura aos princípios fundamentais do liberalismo político, mas tão só do reconhecimento da necessidade de adaptação dos velhos dogmas aos novos tempos.

Os partidos do constitucionalismo monárquico, ainda que sofrendo as primeiras investidas sérias do movimento republicano, procuraram, essencialmente, retirar do centenário dividendos que os robustecessem na luta que travavam entre si (pela conquista do poder político) e contra um clero predominantemente antiliberal (pela direcção efectiva da sociedade).

Enfim, socialistas e republicanos espreitavam o ensejo de combater o poder monárquico e a influência eclesiástica. Especialmente os segundos, verão no centenário um momento privilegiado para a divulgação das suas propostas junto da opinião pública, para se oporem ao "decadentismo" que o regime monárquico e oligárquico impunha em relação aos «valores nacionais", para pugnarem pela laicização integral da sociedade e o fim do controlo clerical das mentalidades e dos indivíduos.

O centenário passou e, em breve, outros sucessos de importância ocupariam 'a atenção daqueles que, em Portugal, viviam a política activa. O território em que se moviam, porém, esse não era já o mesmo... 